\title{
A new prozostrodontian cynodont (Therapsida) from the Late Triassic Riograndia Assemblage Zone (Santa Maria Supersequence) of Southern Brazil
}

\author{
MARINA B. SOARES ${ }^{1}$, AGUSTÍN G. MARTINELLI ${ }^{1}$ and TÉO V. DE OLIVEIRA ${ }^{2}$ \\ ${ }^{1}$ Laboratório do Setor de Paleovertebrados, Departamento de Paleontologia e Estratigrafia, Instituto de Geociências, \\ Universidade Federal do Rio Grande do Sul/UFRGS, Av. Bento Gonçalves, 9500, 90540-000 Porto Alegre, RS, Brasil \\ ${ }^{2}$ Museu de Zoologia, Departamento de Ciências Biológicas, Universidade Estadual de Feira de Santana/UEFS, \\ Av. Transnordestina, s/n, Novo Horizonte, 44036-900 Feira de Santana, BA, Brasil
}

Manuscript received on September 8, 2014; accepted for publication on October 14, 2014

\begin{abstract}
We report here on a new prozostrodontian cynodont, Botucaraitherium belarminoi gen. et sp. nov., from the Late Triassic Riograndia Assemblage Zone (AZ) of the Candelária Sequence (Santa Maria Supersequence), collected in the Botucaraí Hill Site, Candelária Municipality, state of Rio Grande do Sul, Brazil. The new taxon is based on a single specimen (holotype MMACR-PV-003-T) which includes the left lower jaw, without postdentary bones, bearing the root of the last incisor, canine and four postcanines plus one partial crown inside the dentary, not erupted, and two maxillary fragments, one with a broken canine and another with one postcanine. The features of the lower jaw and lower/upper postcanines resemble those of the prozostrodontians Prozostrodon brasiliensis from the older Hyperodapedon AZ and Brasilodon quadrangularis and Brasilitherium riograndensis from the same Riograndia AZ. The inclusion of Botucaraitherium within a broad phylogenetic analysis, positioned it as a more derived taxon than tritylodontids, being the sister-taxon of Brasilodon, Brasilitherium plus Mammaliaformes. Although the new taxon is based on few cranial elements, it represents a additional faunal component of the Triassic Riograndia AZ of southern Brazil, in which small-sized derived non-mammaliaform cynodonts, closely related to the origin of mammaliaforms, were ecologically well succeed and taxonomically diverse.
\end{abstract}

Key words: Cynodontia, Prozostrodontia, Santa Maria Supersequence, Triassic.

\section{INTRODUCTION}

The rich fossil tetrapod content from the MiddleUpper Triassic of southern Brazil is recorded in beds related to the Santa Maria Supersequence, in which four recognized faunal tetrapod associations succeed in time: Dinodontosaurus, Santacruzodon, Hyperodapedon and Riograndia Assemblage Zones (AZ) (Soares et al. 2011) (Fig. 1). In all of these biostratigraphic unities, whose proposed ages are

Correspondence to: Marina Bento Soares

E-mail: marina.soares@ufrgs.br based on correlations with Argentinean and Malagasy faunas (Abdala and Ribeiro 2010), the non-mammaliaform cynodonts (Therapsida, Eucynodontia) account for a significant percentage of the recorded taxa, taxonomically comprising the most diverse group. In fact, the diversity of the derived non-mammaliaform probainognathian cynodonts, grouped into the Clade Prozostrodontia (sensu Liu and Olsen 2010), from the Upper Triassic Candelária Sequence (Santa Maria Supersequence) of southern Brazil is remarkable when compared to 
its global fossil record, based upon poorly preserved specimens. At least two prozostrodontians are known from the Hyperodapedon AZ (Bonaparte and Barberena 2001) and at least five from the younger Riograndia AZ (Bonaparte et al. 2001, 2003, 2005, 2010, 2012, Martinelli et al. 2005, Soares et al. 2011). Recent studies on these taxa have highlighted their essential contribution to the understanding of the mammaliaforms origin (Bonaparte et al. 2005, Luo 2007, Abdala 2007, Liu and Olsen 2010, Bonaparte 2012), illustrating the climbing mosaic of characters developed during the Middle-Late Triassic transition (Bonaparte et al. 2005, Martinelli and Rougier 2007, Martinelli and Bonaparte 2011, Bonaparte 2012, Rodrigues et al. 2012, 2013).

In the late Carnian Hyperodapedon AZ, the prozostrodontians Therioherpeton cargnini Bonaparte and Barberena (1975) and Prozostrodon brasiliensis Bonaparte and Barberena (2001) are recognized, both displaying several derived features in the skull and dentition (e.g. lack of prefrontal and postorbital, constricted root in postcanines) that positioned them as basal prozostrodontians (Liu and Olsen 2010). From this AZ, Charruodon tetracuspidatus Abdala and Ribeiro (2000) and Trucidocynodon riograndensis Oliveira et al. (2010) are also known. Charruodon was originally related to Therioherpeton due to the morphology of the lower postcanines; nonetheless, based on the deep and robust lower jaw (unexpected for Therioherpeton based on its skull), we consider that the phylogenetic position of Charruodon cannot be elucidated until new specimens come to light. On the other hand, Trucidocynodon represents a member of the Ecteniniidae (Oliveira et al. 2010, Martinez et al. 2013), which is positioned outside, as sister-group of Prozostrodontia (Martinez et al. 2013).

With regard to the prozostrodontian content, the early Norian Riograndia AZ includes Riograndia guaibensis Bonaparte et al. (2001) Irajatherium hernandezi Martinelli et al. (2005), Brasilodon quadrangularis, Brasilitherium riograndensis
Bonaparte et al. (2003), and Minicynodon Bonaparte et al. (2010). Riograndia is the most common cynodont of this AZ, represented by several exquisitely preserved specimens. Riograndia is considered as a basal member of the Tritheledontidae Clade (Bonaparte et al. 2001, Soares et al. 2011) or a basal Ictidosauria, sistertaxon of Tritheledontidae (sensu Martinelli et al. 2005, Martinelli and Rougier 2007). Irajatherium is still poorly represented in comparison to other cynodonts from this AZ. However, its dentition resembles that of Chaliminia from the Late Triassic of Argentina and Pachygenelus from the Early Jurassic of Africa (Martinelli and Rougier 2007). Hence, Irajatherium is positioned as a basal Tritheledontidae (Martinelli et al. 2005, Martinelli and Rougier 2007, Oliveira et al. 2011). Brasilodon, Brasilitherium (Bonaparte et al. 2003, 2005, 2012), and Minicynodon (Bonaparte et al. 2010, 2012) are relatively well-documented and they are crucial taxa in cynodont evolution because they constitute the sister-group of Mammaliaformes (e.g., Bonaparte et al. 2003, 2005, 2012, Abdala 2007, Martinelli and Rougier 2007, Luo 2007, Liu and Olsen 2010, Rodrigues et al. 2012, 2013, Ruff et al. 2014). Bonaparte et al. (2005) created the Family Brasilodontidae to include Brasilodon and Brasilitherium, and, subsequently, other taxa were included in it such as Protheriodon estudianti (Bonaparte et al. 2006, Bonaparte 2012). Some authors (e.g., Liu and Olsen 2010) pointed out that Brasilodon and Brasilitherium are synonym and also that a monophyletic Brasilodontidae has not been recovered (e.g., Abdala 2007). Notwithstanding these issues that are currently under revision, the impact that the discovery of the brasilodontids from the Riograndia AZ of southern Brazil has caused is unprecedented (Bonaparte et al. 2003, 2005, 2012, Rodrigues et al. 2012, 2013).

In this contribution, we present a new prozostrodontian cynodont from the Riograndia AZ of 
the Candelária Municipality, state of Rio Grande do Sul, Brazil. The new taxon is described, compared and included in a broad phylogenetic analysis of cynodonts. Although based on a partial lower jaw and maxillary fragments, the specimen represents a new taxon of prozostrodontian

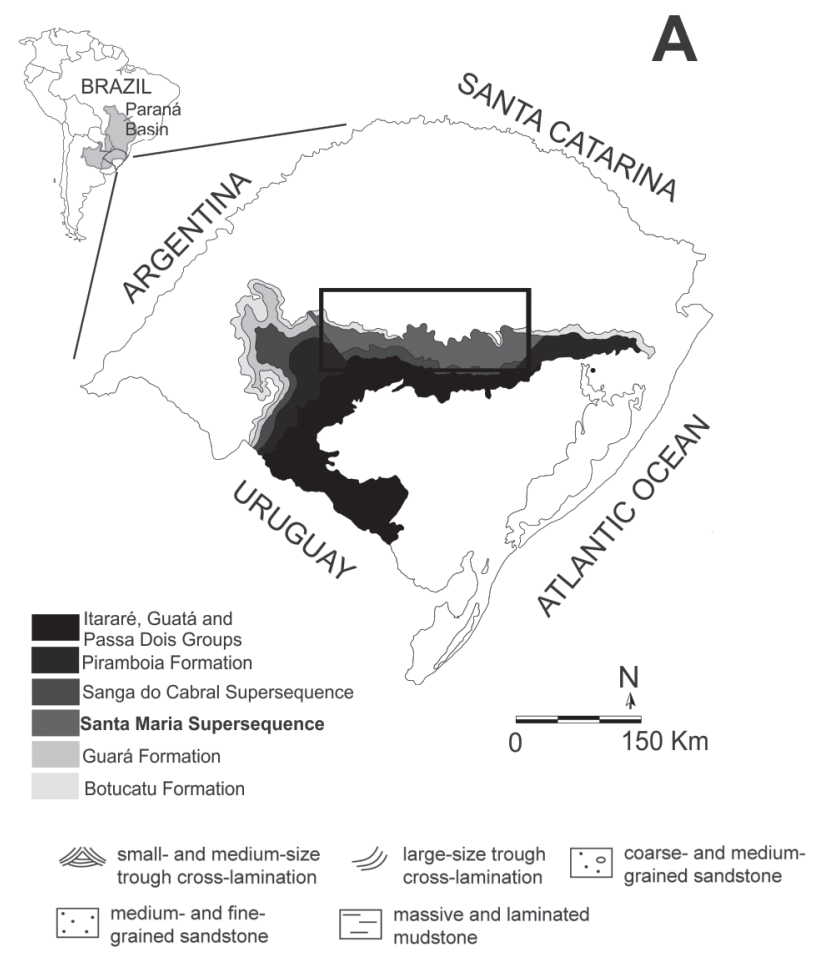

with several features shared with Prozostrodon from the Hyperodapedon AZ and especially with Brasilodon and Brasilitherium from the Riograndia AZ. The new specimen contributes to the understanding of the non-mammaliaform prozostrodontian diversity.

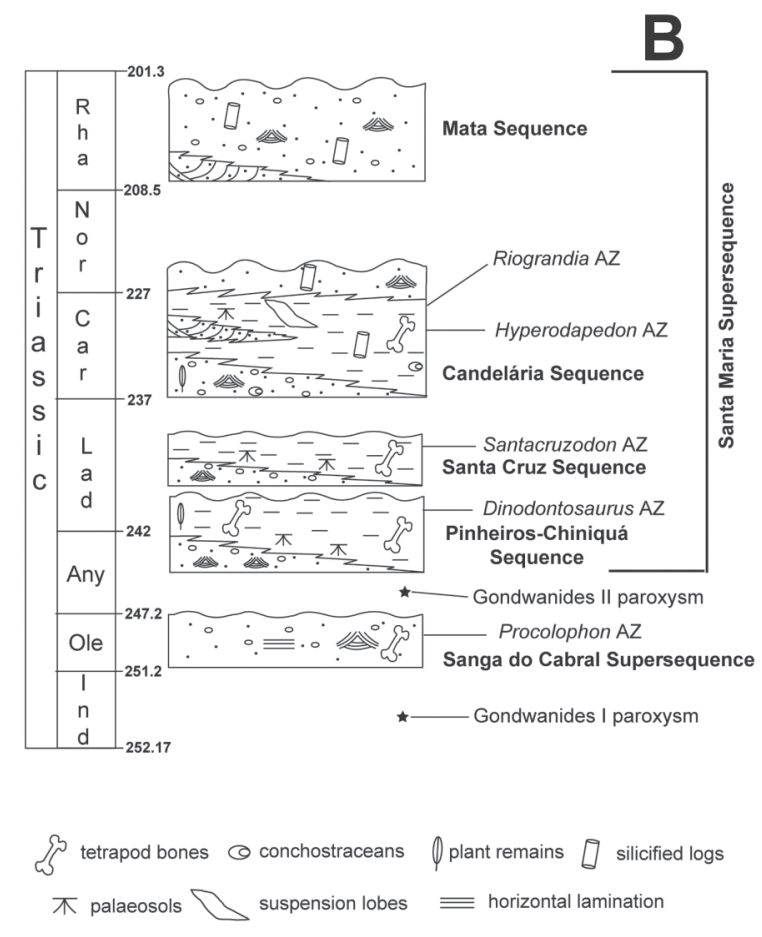

Fig. 1 - A: Geographical location of the Santa Maria Supersequence (Paraná Basin) in the state of Rio Grande do Sul, Brazil. B: Chronostratigraphy of the southern Brazilian Triassic, showing the four Assemblage Zones (AZ) based on tetrapods context. From Horn et al. 2004. Biostratigraphy after Soares et al. 2011. Abbreviations: Any, Anisian; Car, Carnian; Ind, Induan; Lad, Ladinian; Nor, Norian; Ole, Olenekian; Rha, Rhaetian.

\section{GEOLOGICAL SETTING AND BIOSTRATIGRAPHY}

The Upper Triassic Candelária Sequence corresponds to a third-order sequence placed in the Santa Maria Supersequence (sensu Zerfass et al. 2003, Horn et al. 2014) (Fig. 1). The basal portion of the Sequence consists of a coarsening-upward succession that begins with red mudstones interbedded with small-scale trough cross-bedded sandstone lenses. Rhytmites and sigmoidal massive to climbing cross-laminated sandstone bodies are also present (Soares et al. 2011). This facies association is interpreted as a lacustrinedeltaic depositional system in a humid climate (Holz and Scherer 2000, Zerfass et al. 2003). The Candelária Sequence encompasses the Hyperodapedon AZ (sensu Abdala et al. 2001), in which the most abundant components are the rhynchosaur Hyperodapedon sp. and the traversodontid cynodont Exaeretodon riograndensis Abdala et al. (2002). Besides the aforementioned cynodonts (e.g., Trucidocynodon, Therioherpeton, Charruodon and Prozostrodon), its dinosaur content also deserves mention (Bittencourt and Kellner 2009, Langer et al. 1999, Cabreira et al. 2011). This faunal association enables us to correlate these levels with those of the Ischigualasto Formation from Argentina, whose basal layer was dated as 
230.3-231.4 \pm 0.3My (Rogers et al. 1993, Furin et al. 2006, Martinez et al. 2011). The top of the Candelária Sequence, where the younger Riograndia AZ is recognized, has an increased content of sandstone. The layers occur as narrow, massive or stratified (horizontal and trough cross bedding) lenses interpreted as amalgamated sandstone bodies related to high width/depth ratio channels. This succession is interpreted as the progressive replacement of a lacustrine-deltaic by a fluvial system (Rubert and Schultz 2004, Soares et al. 2011). The Riograndia AZ is characterized by a rich association of small tetrapods, such as the procolophonid Soturnia caliodon Cisneros and Schultz (2003), and the sphenodontid Clevosaurus brasiliensis Bonaparte and Sues (2006), among others, and the five taxa of advanced non-mammaliaform cynodonts aforementioned (Riograndia, Brasilodon, Brasilitherium, Irajatherium and Minicynodon). The dinosaurs are represented by the plateosaurid Unaysaurus tolentinoi Leal et al. (2003), the theropod (sensu Langer et al. 2009) Guaibasaurus candelariensis Bonaparte et al. (1999), and new specimens with sauropodomorph affinities (Bittencourt et al. 2013), plus the dinosauriform Sacisaurus agudoensis Ferigolo and Langer (2007). Also compose the Riograndia AZ the dicynodont Jachaleria candelariensis Araújo and Gonzaga (1980), an indeterminate phytosaur (Kischlat and Lucas 2003), isolated teeth of archosaurs (Dornelles 1990), and a stereospondyl amphibian (Dias-da-Silva et al. 2009). This whole fauna occurs in a series of outcrops mainly located in Candelária and Faxinal do Soturno municipalities, and the record of Riograndia guaibensis in at least five of them, enables their correlation to the Riograndia AZ (Soares et al. 2011, Bittencourt et al. 2013). In turn, Riograndia AZ can be correlated to the fauna from the base of the Los Colorados Formation of Argentina (Early Norian) due to the presence of the same dicynodont genera, Jachaleria (Bonaparte 1971, see also comments in Martinelli and Rougier 2007).
The Botucaraí Hill Site (sensu Bittencourt et al. 2013) crops out along the highway BR 287, Candelária Municipality, state of Rio Grande do

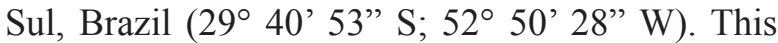
site is characterized by twelve meters of massive to laminar mudstones intercalated by centimeter massive sandstones lenses, followed by a layer of massive sandstones and another layer of trough cross bedded sandstone, one meter thick each. The holotype of the new cynodont was collected at the same level where several materials of Jachaleria and some sauropodomorph dinosaur remains were found (Bittencourt et al. 2013) (Fig. 2).

\section{SYSTEMATIC PALEONTOLOGY}

THERAPSIDA Broom, 1905

CYNODONTIA Owen, 1861

EUCYNODONTIA Kemp, 1982

PROBAINOGNATHIA Hopson, 1990

PROZOSTRODONTIA Liu and Olsen, 2010

Botucaraitherium gen. nov.

DiAGNOSIS

Botucaraitherium is diagnosed by the following association of characters: upper postcanines with a prominent central cusp (A), with symmetric mesial and distal edges, two cusps mesio-lingually (cusp B) and disto-lingually (cusp $\mathrm{C}$ ) arranged (being $\mathrm{A}>>\mathrm{B}=\mathrm{C}$ ), and two accessory cuspules in the mesio-labial border and one cuspule in the disto-labial edge; the three main upper cusps form a subtle angle (opposite to the condition of the "reverse triangle pattern"); lingual surface of the crown of upper postcanines slightly concave, with a flexion; lower postcanines with a main large cusp a on the mesial half of the crown, followed by cusps c and d decreasing in size posteriorly, slightly curved backward; main cusp a totally asymmetrical, with a concave mesial edge and is about two times taller than the straight distal 

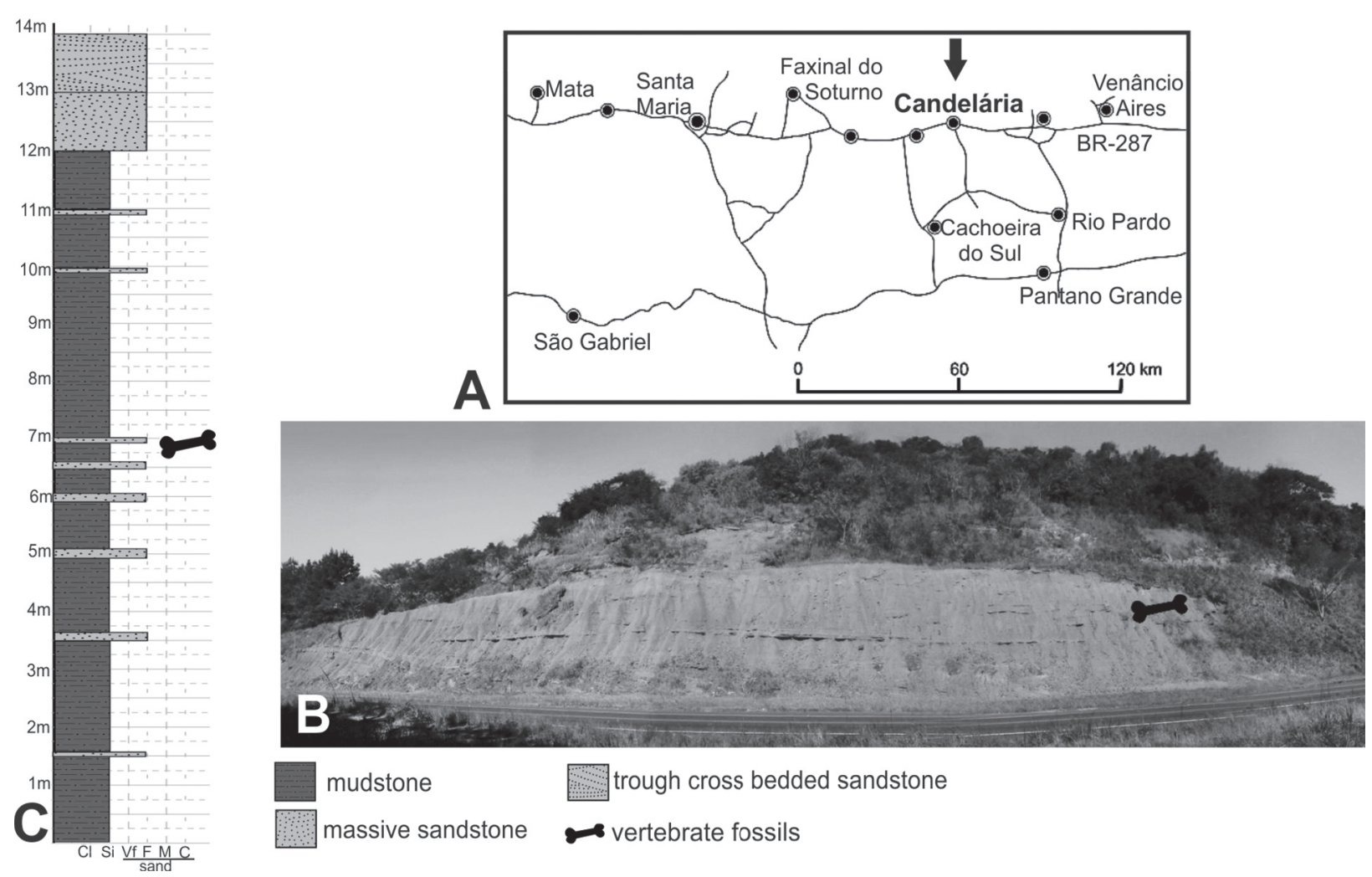

Fig. 2 - A: Road map with City of Candelária indicated. B: View of the Botucaraí Hill site, southern margin of BR 287 road, with the indication of the fossiliferous level. C: Log of the Botucaraí Hill Site.

edge; cusps $\mathrm{c}$ and $\mathrm{d}$ with symmetrical mesial and distal edges; reduced and basal positioned cusp b (cusp a $>c>d>>b$ ); lower postcanines with multicuspidated lingual cingulum shelf, with small mesial cusp e; upper and lower postcanines with 8-shaped cross-section root; large diastema between canine and postcanines in adult stage; postcanine replacement including the loose of anterior postcanines, addition of new ones at the rear and substitution of other functional teeth.

\section{TYPE AND ONLY KNOWN SPECIES}

Botucaraitherium belarminoi sp. nov.

ETYMOLOGY

Botucarai, in reference to the Botucaraí Hill, which dominates the landscape of the Candelary City (state of Rio Grande do Sul) and where there are several outcrops with Triassic fauna. In one of these outcrops, Botucaraí Hill Site (sensu Bittencourt et al. 2013) the holotype was found. Therium, from the New Latin, that derives from the Greek therrion, which means "beast", frequently used in mammals and close relative forms.

Botucaraitherium belarminoi sp. nov.

HoLOTYPE

MMACR-PV-003-T, left lower jaw, without postdentary bones, bearing the root of last incisor, the canine, and four partially preserved postcanines plus one partial crown inside the dentary (not erupted), and two left maxillary fragments, one with a broken canine and the other with one postcanine and the root of the following two teeth.

\section{DIAGNOSIS}

Same as for genus. 


\section{ETYMOLOGY}

belarminoi, named in honor of Mr. Belarmino Stefanello, a volunteer at the Museu Municipal Aristides Carlos Rodrigues, who found the fossil.

\section{LOCALITY AND HORIZON}

From the Botucaraí Hill Site (sensu Bittencourt et al. 2013) near the level where the dicynodont Jachaleria (Aráujo and Gonzaga 1980) and dinosaur remains with sauropodomorph affinities (Bittencourt et al. 2013) were recovered. It is located about 8 kilometers west of Candelária City, in a roadcut of the route BR-287, state of Rio Grande do Sul, Brazil (Fig. 2), Candelária Sequence, Santa Maria Supersequence (Zerfass et al. 2003, Horn et al. 2014), Riograndia AZ (Soares et al. 2011), possibly Early Norian (Fig. 1).

DESCRIPTION

The specimen MMACR-PV-003-T is mostly not well-preserved due to several breakages in the lower jaw and the maxillary fragments are isolated (Fig. 3). Only the lower canine, one upper and some lower postcanines preserve most of their crown. All the material included in the holotype specimen was found in association and corresponds to only one individual.

\section{MAXILLA}

The two available portions of maxilla are extremely fragmented, without much information. Based on the preserved teeth, they correspond to the left side of the skull. One of the fragments, which preserves the left canine, has the external surface anteroposteriorly concave, highlighting the prominent canine root (Fig. 3A). Just posterior to it there is a small foramen, facing anteriorly. The second fragment has a complete anterior postcanine and the two 8 -shaped roots of the two following ones (described later) (Fig. 3B). Above the first broken postcanine (i.e. the first root) there is a concavity and subtle notch which possibly corresponds to a large exit of the infraorbital branch of the trigeminal nerve.
LOWER JAW

The dentary is only observed in medial view (Fig. 4). The jaw is anteroposteriorly larger than any of the known specimens of Brasilodon, Brasilitherium and Minicynodon from the same Riograndia AZ, and smaller than Prozostrodon from the Hyperodapedon AZ. The horizontal ramus is slender along the anterior half and becomes slightly deeper at the rear. Therefore, the alveolar level and the ventral margin of the horizontal ramus are slightly divergent posteriorly. The mandibular symphysis is unfused as in prozostrodontians (e.g., Prozostrodon, Brasilodon, Brasilitherium; Bonaparte and Barberena 2001, Bonaparte et al. 2003, 2005) and has some longitudinal ridges and a small foramen. The trough for the postdentary bones is relatively reduced and runs forward, becoming smaller, parallel to the ventral edge of the dentary. The dentary seems to be transversely wide at the angular process; this region is not well-preserved although its shape seems to be similar to that of Prozostrodon (UFRGS-PV0248-T). Below the alveolar line, the dental lamina is observed, mainly at the level of the fourth postcanine. The dentary has a large diastema between canine and postcanines and the canine base and alveolar level of the incisor is positioned slightly dorsal to the alveolar level of the postcanine series (Fig. 4A). This condition is similar to that observed in Prozostrodon, Brasilodon, Brasilitherium (Bonaparte and Barberena 2001, Bonaparte et al. 2003, 2005) and other possibly related forms such as Microconodon and Dromatherium (Hahn et al. 1994, Sues 2001).

The coronoid process is broad anteroposteriorly and tall dorsoventrally (Fig. 4A). It rises behind the pc4 where its base is more transversely broad than the remaining edge. A clear scar for the coronoid bone is not observable at this region, possibly due to the bad preservation. The articular process of the dentary is broken at the rear, nonetheless it seems to be well-developed as in other prozostrodontians (e.g., Prozostrodon, Brasilodon). 

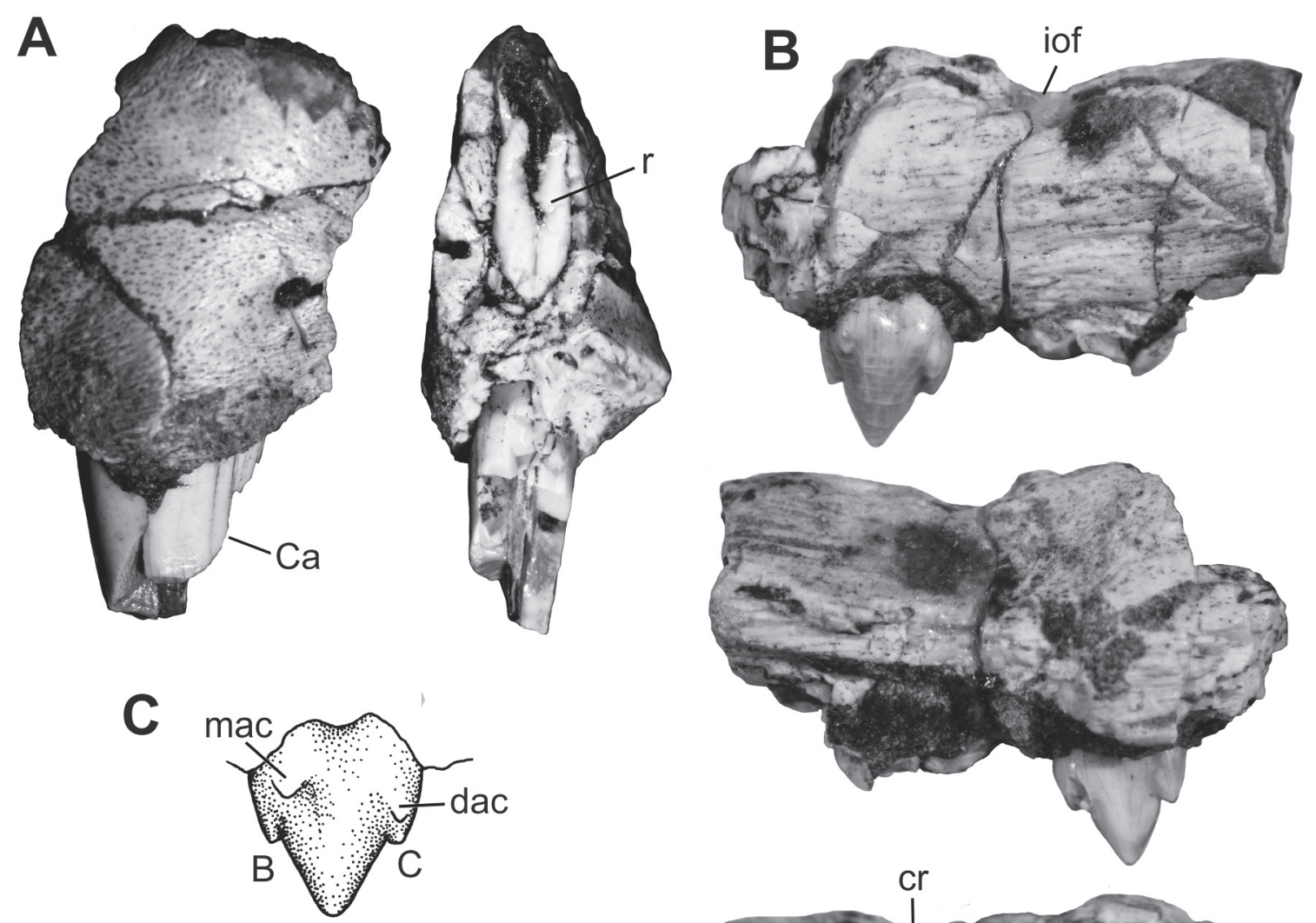

A
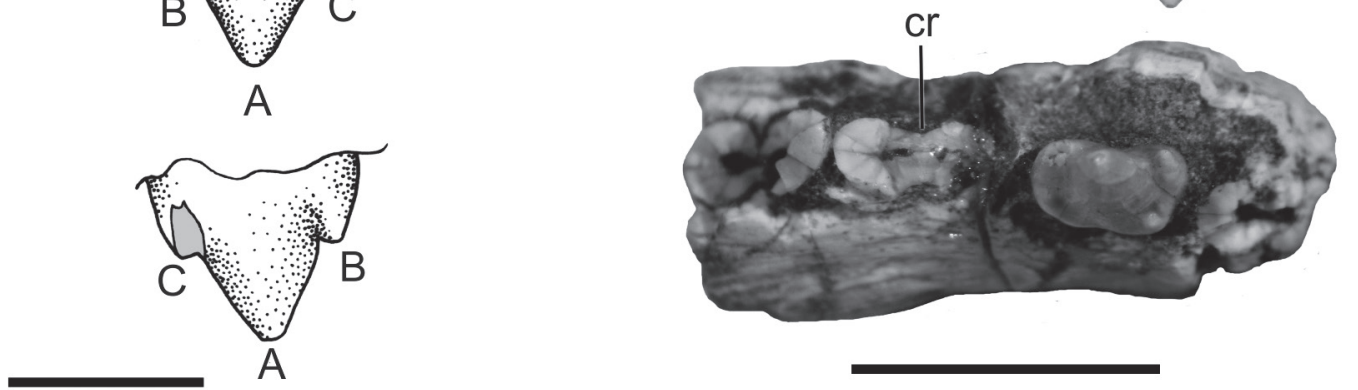

Fig. 3 - Holotype (MMACR-PV-003-T) of Botucaraitherium belarminoi gen. nov. et sp. nov. A: Fragment of left maxilla with portion of canine in lateral and posterior views. B: Fragment of left maxilla with postcanine in lateral, medial and ventral views. C: Detail of upper postcanine in labial (lateral) and lingual (medial) views. Scale bars equals $5 \mathrm{~mm}$ in $\mathrm{A}$ and $\mathrm{B}$ and $2 \mathrm{~mm}$ in C. Gray areas indicate broken surfaces. Abbreviations: A-C, refers to name of cusps; Ca, upper canine; cr, constricted root; dac, distal accessory cuspule; iof, ventral edge of the infraorbital foramen; mac, mesial accessory cuspule; r, root.

Only the anterior $1 / 3$ portion of the horizontal ramus of the dentary can be observed in lateral view. The surface is slightly convex dorso-ventrally and there are at least two small mental foramina below and anteriorly to the level of the canine.

\section{UPPER DENTITION}

The upper incisors are not preserved. One fragment of maxilla keeps the left canine which is partially broken. It is elliptical in cross section, at the base, twice mesio-distally longer than transversely wide. The preserved mesial and distal edges are gently concave, without evidence of a ridge or crenulations (Fig. 3A). The mesial edge is subtle convex whereas the distal one is straight to slightly concave. The upper canine is larger than the lower one.

The other fragment of maxilla preserves one postcanine and the root of the following two (Fig. 3A). Unfortunately, there is no contact between both maxillary fragments, precluding any detail of the 
first postcanine and the condition of the diastema. In addition, the upper postcanine count is unknown as is the exact position of the preserved postcanine.

The preserved postcanine has the crown as long as tall, mesio-distally, and about two times long than wide. The crown is dominated by a central cusp (A), with symmetric mesial and distal edges, and two cusps mesio-lingually (cusp B) and disto-lingually (cusp $\mathrm{C}$; the tip of this cusp is broken) arranged. Cusps B and $\mathrm{C}$ have quite similar sizes but cusp B is positioned slightly more dorsal than cusp C. In oclusal view, the three cusps form a subtle angle, opposite to the condition observed in mammaliaforms with the reverse triangle pattern (Crompton and Jenkins 1968). In addition, there are accessory cingular cuspules on the labial side. On the mesio-labial corner there are two tiny cuspules (the more mesial the smallest) which are the most dorsally positioned cusps of the crown. Hence, there is some considerable distance between these cuspules and cusp B. Also, these accessory cuspules make the mesial width of the crown slightly wider than the distal width. The disto-labial accessory cusp is near cusp C, at its dorsal base (Fig. 3C). In oclusal view the labial surface of the crown is fairly straight whereas the lingual one is concave, with a flexion. The root of this postcanine is entirely inside the alveolus, but in labial view, the beginning of a longitudinal groove can be observed, constricting the root. The size of the only known upper postcanine is considerably smaller than the lower ones, a condition observed in some other probainognathians (e.g., Prozostrodon, Brasilodon, Irajatherium, Bonaparte and Barberena 2001, Bonaparte et al. 2003, 2005, Martinelli et al. 2005).

The upper postcanine pattern of the Botucaraitherium is quite different from those of the tritheledontids (Irajatherium, Chaliminia), in which there are a mesiodistally compressed and transversely broad main cusp, with small mesial and distal cusps (with a labial cingulum in the postcanines of Pachygenelus; Gow 1980, Martinelli et al. 2005,
Martinelli and Rougier 2007). Botucaraitherium also differs from Riograndia because the latter taxon has up to nine cusps mesiodistally aligned without any cingulum (Bonaparte et al. 2001, Soares et al. 2011). The upper postcanines of Prozostrodon display four aligned cusps (A, B , C, D) (Bonaparte and Barberena 2001) without lingual cusps or any cingular cuspules. Thus, the upper postcanines of Botucaraitherium differ significantly from those of Prozostrodon in having three main cusps (instead of four) plus accessory labial cingular cuspules (Fig. 5A, B).

The upper postcanine pattern of Botucaraitherium is more closely related to that of Brasilodon, Brasilitherium and Minicynodon (Fig. 5A, C) (Bonaparte et al. 2003, 2005, 2010, 2012) than to any other prozostrodontian. Regarding the brasilodontids, its postcanines have a prominent central cusp (A), one mesial (B) and one distal (C), small accessory cusps aligned on the lingual side, and one mesial and one distal small cusp on the labial side, giving a symmetrical cusp arrangement. This pattern is consistent in all specimens of Brasilodon and Minicynodon, but in some specimens referred to Brasilitherium the distal labial accessory cusp is placed more posteriorly (Bonaparte et al. 2010, Martinelli and Bonaparte 2011).

Botucaraitherium is differentiated from brasilodontids by a notoriously more bulbous crown and two (not one) mesio-labial accessory cusps. These features have never been observed even in the largest specimens of the aforementioned brasilodontids. Therefore, we considered this feature as unique of Botucaraitherium, since in the large sample of brasilodontids from the Riograndia AZ, this condition was never observed.

In addition to the only preserved upper postcanine, the maxillary fragment preserves the root of the two following teeth. The roots increase in size posteriorly and are 8-shaped in cross-section, in which the longitudinal groove is present in both labial and lingual sides, with each lobe having its own root canal. 


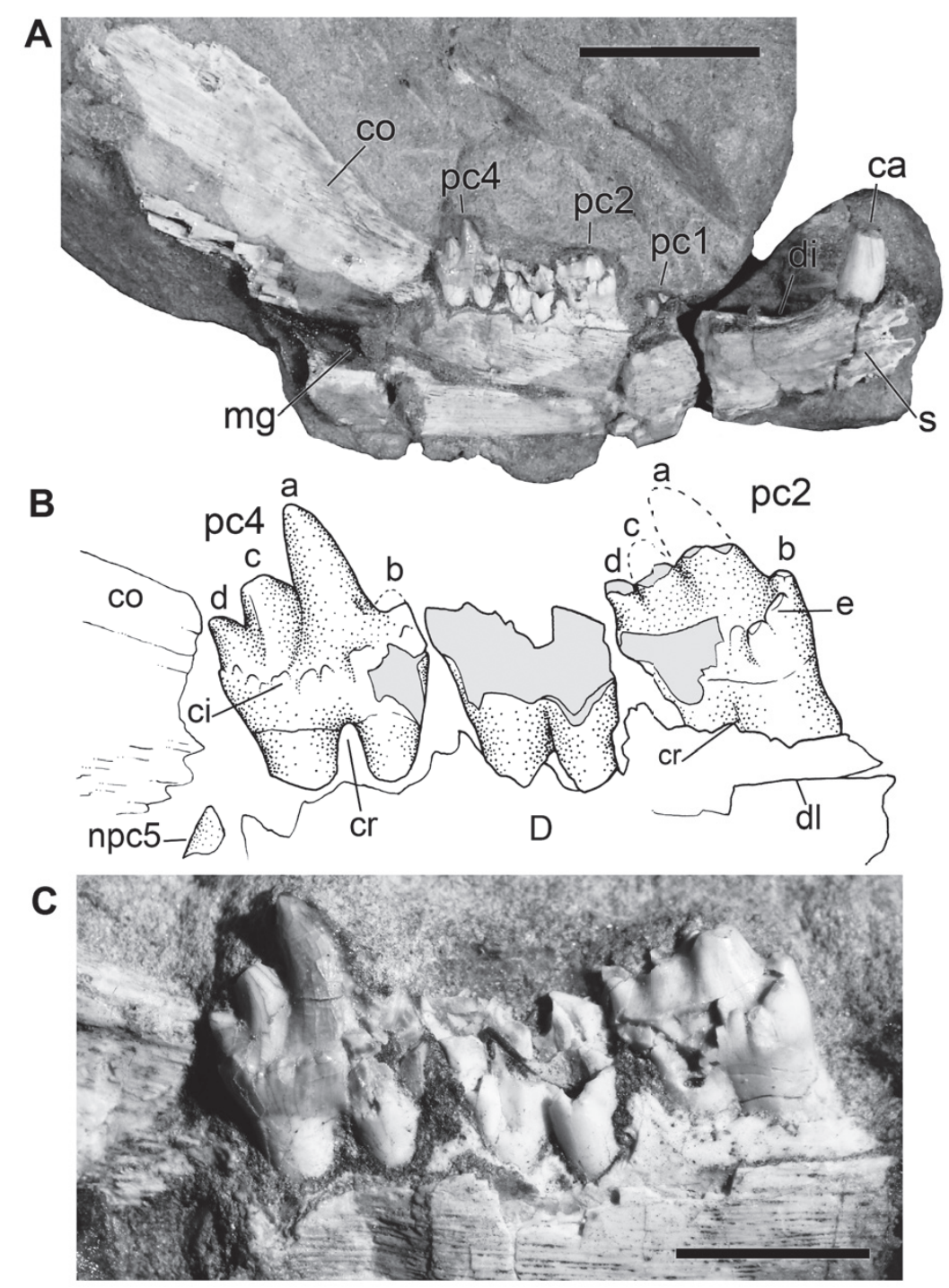

Fig. 4 - Holotype (MMACR-PV-003-T) of Botucaraitherium belarminoi gen. nov. et sp. nov. A: Left lower jaw in medial view. $\mathbf{B}$ and $\mathbf{C}$ : detail of the postcanines in medial view. Scale bar equals $10 \mathrm{~mm}$ in $\mathbf{A}$ and $3 \mathrm{~mm}$ in $\mathbf{B}$. Gray areas indicate broken surfaces. Abbreviations: a-e, refers to name of cusps; ca, canine; ci, cuspidated cingulum; co, coronoid process of dentary; cr, constricted root; D, dentary; dl, dental lamina; mg, meckelian groove; npc5, non-erupted postcanine 5; pc, postcanine; s, symphysis.

\section{LOWER DENTITION}

The number of lower incisors is unknown. The root of the last incisor is preserved, which is circular in cross-section. It is next to the canine, indicating the lack of a diastema. Anteriorly to this root, the dentary is partially broken off and it is impossible to deduce the number and size of the other incisors (Fig. 4A). In Brasilodon there are three incisors and based on its dentary morphology the number of incisors for Botucaraitherium is likely to be the same.
The canine is broken at the tip (Fig. 4A). It is sub-circular in cross-section, with the mesial edge slightly convex and the distal one slightly concave. On the distal edge there is a thin longitudinal ridge, without serrations. The enamel covering the crown is very thin and a large portion of the root is observed outside the alveolus. There is a large diastema between the canine and the postcanines. Along the posteriormost portion of the diastema there is a mesio-distally oriented sulcus that could 


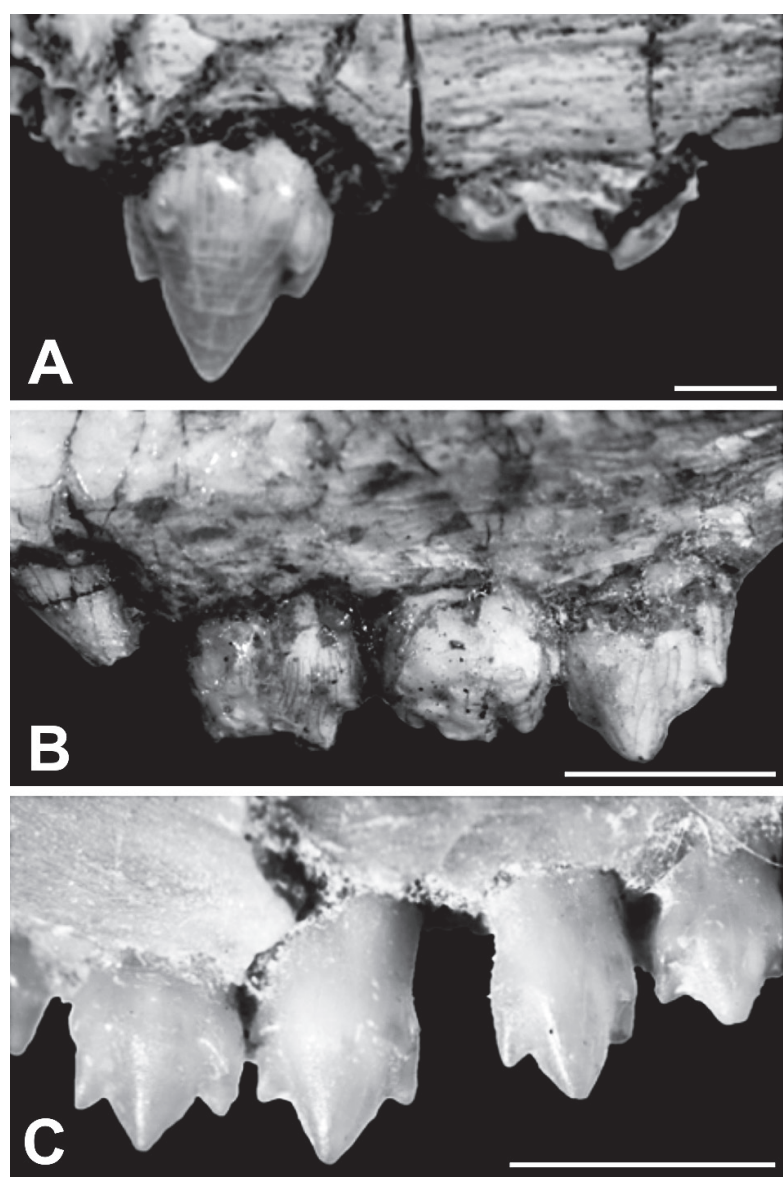

Fig. 5 - Comparisons of upper postcanines. A: Botucaraitherium belarminoi gen. nov. et sp. nov (Holotype MMACR-PV-003-T) in left labial view. B: Prozostrodon brasiliensis (Holotype UFRGSPV-0248-T) in left labial view. C: Brasilodon quadrangularis (Holotype UFRGS-PV-0611-T) in right labial view. Scale bar equals $1 \mathrm{~mm}$.

correspond to closed alveoli of the lost teeth. The loss of the anterior postcanines and concomitantly the enlargement of the diastema are a pattern observed in several taxa, such as some tritylodontids (e.g., Oligokyphus, Tritylodon; Kemp, 1982) Brasilodon and Brasilitherium (Martinelli and Bonaparte 2011), and some early mammaliaforms (e.g., Sinoconodon; Crompton and Luo 1993, Luo et al. 2004).

The postcanine series includes five teeth (Fig 3). The $\mathrm{pcl}$ consists of a main cusp that was in process of eruption. Unfortunately, at this region there is a large breakage that obscures the anatomy of the tooth.
The pc 2-4 are similar in size. Although the crown of pc2 and pc3 are extremely damaged, they show similar crown morphology. There is a main large cusp (a) on the mesial half of the crown, followed by two cusps ( $\mathrm{c}$ and $\mathrm{d}$ ) that decrease in size posteriorly. These three cusps are slightly posteriorly projected, but not to the degree of, for example, Chiniquodon (Abdala and Giannini 2002). The cusps are not bulbous and constitute the sectorial portion of the crown. Cusp a is totally asymmetrical with the mesial edge concave and about two times taller than the straight distal edge. Cusps $\mathrm{c}$ and $\mathrm{d}$ have symmetrical mesial and distal edges. On the mesio-labial edge of the crown, in a basal position, there is a small cusp b. In the pc2 and pc4 that better preserve the crown morphology, the cusp size is $a>c>d>>b$. In the lingual side of the postcanines there is a well-developed cingulum with a small mesial cusp e (better observed in pc2), followed by a series of tiny cuspules that reach the distal margin of the crown, forming a cingular shelf (Fig. 4B, C).

The posteriormost portion of the pc4 lies internally to the coronoid process. The postcanine roots are incipiently bifurcated, with a well-developed longitudinal groove. Just below the pc4, there is a main cusp (a) of a non-erupted last postcanine.

The tooth morphology of Botucaraitherium is reminiscent of Prozostrodon and brasilodontids. The multicuspidated lingual cingular shelf of Botucaraitherium is similar to that of Prozostrodon. In contrast, Brasilodon and Brasilitherium have less crenulated labial cingulum, and instead there are more discrete cuspules (cusps e and g) (e.g., UFRGS-PV-0603-T). With regard to the main cusps, the crown is taller in Botucaraitherium than in Prozostrodon, and in the latter taxon, cusps a, b and $\mathrm{c}$ are more bulbous (less sectorials) with less contrast in height among them (Fig. 6).

\section{TOOTH REPLACEMENT}

The information on a single lower jaw is limited but a few comments on tooth replacement are possible. The large diastema posteriorly to the canine and 

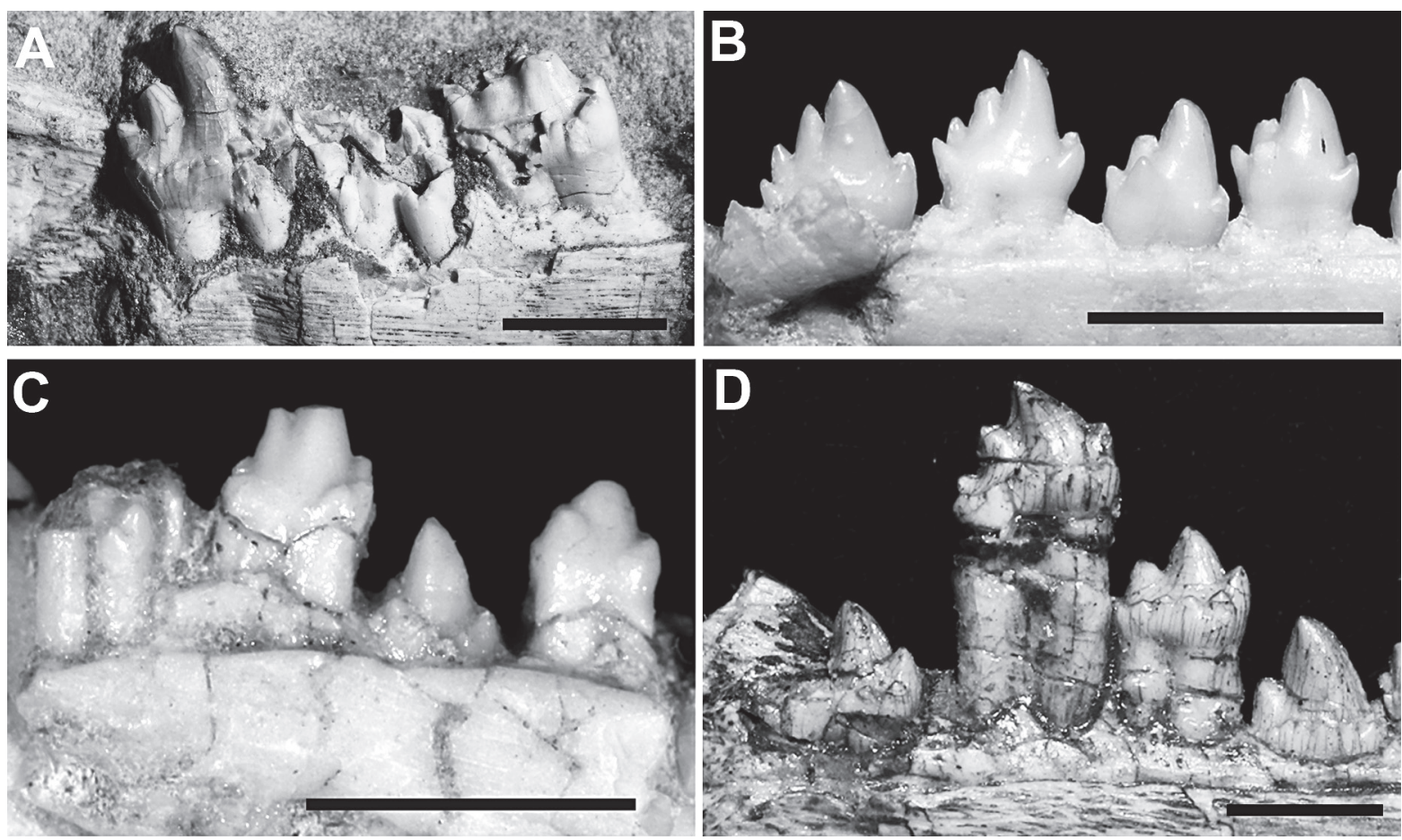

Fig. 6 - Comparisons of the right posterior lower postcanines in lingual view. A: Botucaraitherium belarminoi gen. nov. et sp. nov (Holotype MMACR-PV-003-T). B: Brasilitherium riograndensis (UFRGS-PV-0603-T); C: Brasilodon quadrangularis (UFRGS-PV-0765-T). D: Prozostrodon brasiliensis (Holotype UFRGS-PV-0248-T). Scale bar equals $3 \mathrm{~mm}$.

the closed mesial alveoli, indicate that the anterior most postcanines were lost and not replaced. The anteriormost postcanine (i.e., labeled along the text as pc1) partially inserted in the alveolus shows that some teeth of the series were replaced and the last postcanine ( $\mathrm{pc5}$ ), represented by a non-erupted tooth, indicates that new teeth were added at the rear. Among prozostrodontians, some mix of alternate and sequencial replacement was observed in Brasilodon and Brasilitherium, being apparently polyphyodonty taxa (Bonaparte et al. 2003, 2005, Martinelli and Bonaparte 2011). It should be emphasized that the sequence of postcanine eruption and the number of replacement per locus at the non-mammaliaform prozostrodontians-mammaliaforms boundary is a matter still poorly understood.

\section{DISCUSSION}

Botucaraitherium belarminoi constitutes a new prozostrodontian cynodont from the Riograndia AZ of southern Brazil. The holotype represents an adult individual, larger than any known brasilodontid from the same AZ. There are no recorded specimens of Brasilodon and Brasilitherium in the Botucaraí Hill Site. In turn, these taxa are relatively abundant in the Sesmaria do Pinhal 1 Site, located about 600 meters away (Bonaparte et al. 2003, 2005). In addition, within the Botucaraí region there is a record of Brasilitherium-like teeth in Sesmaria do Pinhal 3 Site, located about 1000 meters away from the Botucaraí Hill Site (Soares et al. 2011, Bittencourt et al. 2013).

The new species is clearly related to prozostrodontians, and especially to Brasilodon and Brasilitherium (Bonaparte et al. 2003, 2005), due to the morphology of the upper and lower postcanines (see Fig. 5, 6). They can be differentiated by the presence in Botucaraitherium of a well-developed multicuspidated lingual cingular shelf in lower postcanines and more bulbous upper postcanines, with more than one mesio-labial accessory cuspules. 
Its resemblance to Prozostrodon, from the older Hyperodapedon AZ, is also noteworthy. The lower dentition of both taxa is quite similar, especially because of the multicuspidated lingual cingular shelf. However, the sectorial portion of the postcanines of Botucaraitherium seems to be less bulbous with taller main cusps. The upper postcanines have stronger differences, due to the fact that the teeth of Prozostrodon are less quadrangular (with the exception of the last non-erupted postcanine of the holotype), and with three more developed accessory cusps in relation to the main cusp.

\section{Phylogenetic ANALYSIS}

A parsimony analysis was performed based on 34 taxa and 145 morphological cranial, dental and postcranial characters (see Appendices 1 and 2), modified from the matrix presented by Liu and Olsen (2010). Some characters and codifications were modified (Appendix 1) and two new terminal taxa (i.e., Brasilitherium riograndensis and Botucaraitherium belarminoi) were added. Liu and Olsen (2010) considered Brasilodon and Brasilitherium as synonyms; therefore, they used only Brasilodon as a terminal taxon. The proposal synonymy for these two species is a matter not clearly understood yet (see for example, Martinelli and Bonaparte 2011, Bonaparte et al. 2012) and will be further analyzed. We considered them as separate taxa in the current analysis.

The data matrix (Appendix 2) was analyzed using Maximum Parsimony with equally weighted characters with the computer program TNT 1.1 (Goloboff et al. 2008). All characters were treated as non-additive. The equally weighted parsimony analysis was conducted performing a heuristic search of Wagner trees with 500 random addition sequences, followed by TBR (Tree Bisection Reconnection), and saving 20 trees per round, which improve the searches and ensures to find all optimal trees.

Our analysis resulted in four most parsimonious trees of 441 steps, with a consistency index (CI)

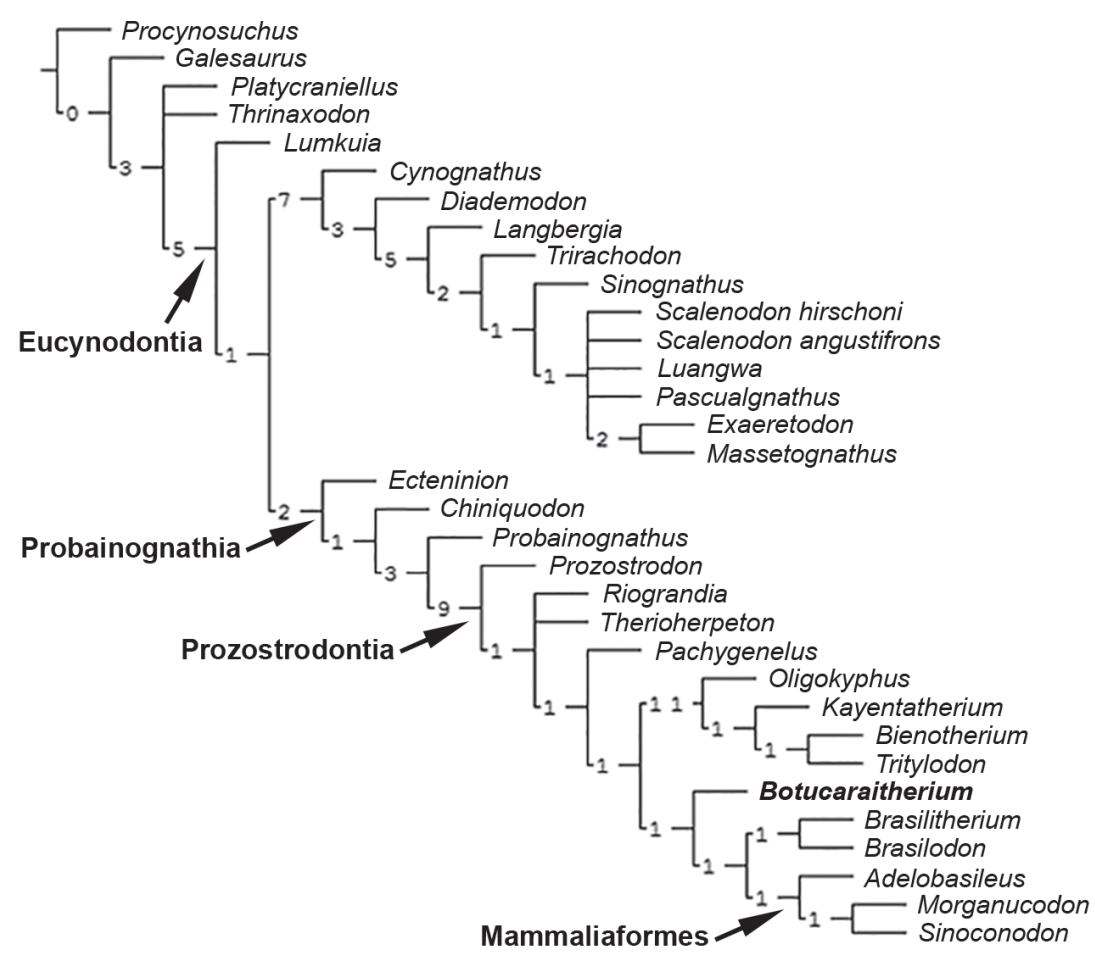

Fig. 7 - Strict consensus tree with Bremer index, positioning Botucaraitherium belarminoi gen. nov. et $\mathrm{sp}$. nov as a derived prozostrodontian. 
of 0.481 and a retention index (RI) of 0.780 . The strict consensus and Bremer index of each node are shown in Figure 7.

In the four most parsimonious trees obtained, the affinities of Botucaraitherium with the brasilodontids are supported. Indeed, Botucaraitherium is positioned as a more derived taxon than tritylodontids, as the sister group to the clade composed by Brasilodon and Brasilitherium plus Mammaliaformes. Despite the fragmentary aspect of the new taxon, especially the characters of the dentary and dentition give support to this relationship.

The presence of Botucaraitherium in the Riograndia AZ (Fig. 8), adding to the already known brasilodontids, reinforces the idea that the nonmammaliaform prozostrodontians enjoyed their greater representativeness during the Late Triassic in South America, which outlined the evolutionary scenery where the most profound anatomical steps related to the origin of mammaliaforms have taken place.

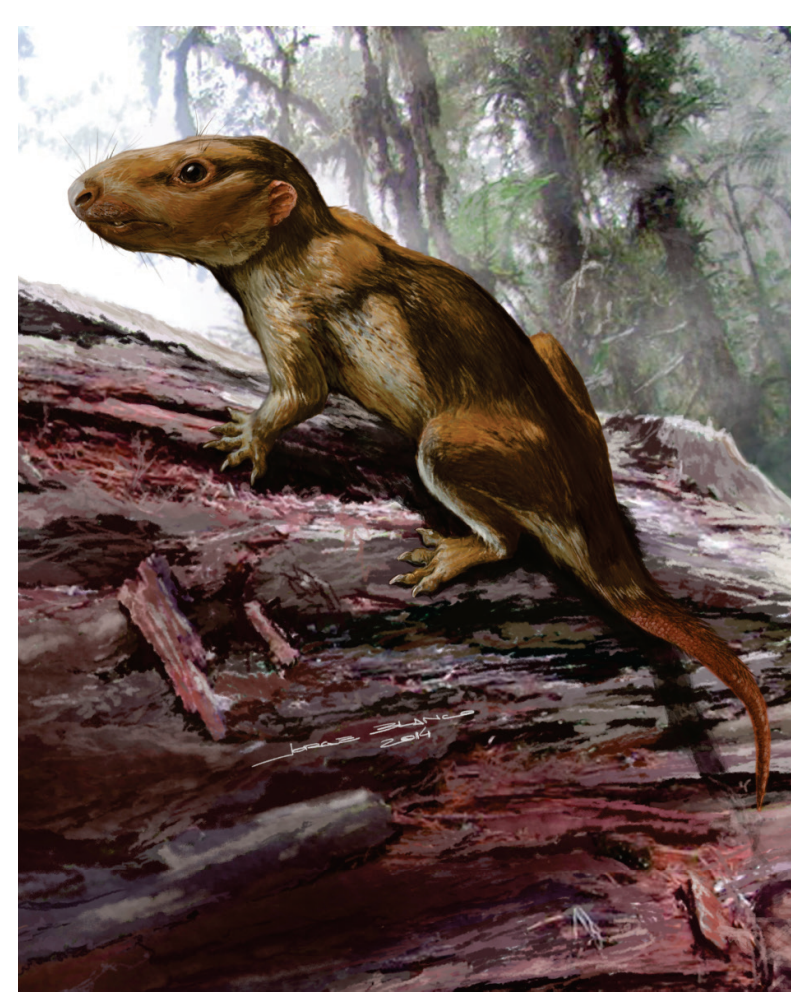

Fig. 8 - Artistic reconstruction of Botucaraitherium belarminoi gen. et sp. nov., by Jorge Blanco.

\section{ACKNOWLEDGMENTS}

The authors thank Carlos Nunes Rodrigues, Curator of the Museu Municipal Aristides Carlos Rodrigues (Candelária, RS), for permitting the study of the specimen MMACR-PV-003-T. The authors would also like to thank Bruno L.D. Horn for providing the Figure 2 and for the Botucaraí Hill Site stratigraphic profile (Fig. 3) and Luiz Flávio Lopes for the photographs. We also thank to Jorge Blanco for the skillful drawing of Botucaraitherium (Fig. 8). Funds were provided by the Conselho Nacional de Desenvolvimento Científico

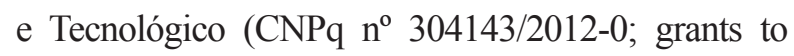
MBS and AGM). We are grateful for the comments of Dr. Guillermo Rougier, Dr. Ricardo Martinez, the anonymous reviewer and the Editor of $\mathrm{AABC}$, Dr. Alexander Kellner, which greatly improved the Ms.

INSTITUTIONAL ABBREVIATIONS

MMACR-PV-T, Museu Municipal Aristides Carlos Rodrigues, (Paleovertebrates, Triassic collection), Candelária, Rio Grande do Sul, Brazil; UFRGSPV-T, Universidade Federal do Rio Grande do Sul (Paleovertebrates, Triassic collection), Porto Alegre, Rio Grande do Sul, Brazil.

\section{RESUMO}

Nós reportamos aqui um novo cinodonte prozostrodonte, Botucaraitherium belarminoi gen. et sp. nov., do Triássico Tardio da Zona de Assembleia (ZA) de Riograndia da Sequência Candelária (Supersequência Santa Maria), coletado no afloramento Sítio Botucaraí, no município de Candelária, Rio Grande do Sul, Brasil. O novo táxon está baseado em um único espécime (holótipo MMACR-PV003-T) o qual inclui a mandíbula esquerda, sem os ossos pós-dentários, com a raiz do último incisivo preservada, o canino e quatro dentes pós-caninos, além de uma coroa parcial, não erupcionada, do quinto pós-canino, e dois fragmentos maxilares, um com um canino quebrado, e outro portando apenas um dente pós-canino. As feições mandibulares e dentárias assemelham-se àquelas dos cinodontes prozostrodontes Prozostrodon brasiliensis da ZA de Hyperodapedon, mais antiga, e de Brasilodon 
quadrangularis e Brasilitherium riograndensis da mesma ZA de Riograndia. A inclusão de Botucaraitherium em uma ampla análise filogenética posicionou-o como um táxon mais derivado do que os tritilodontídeos, sendo o táxon-irmão de Brasilodon, Brasilitherium e mais Mammaliaformes. Apesar de o novo táxon ser baseado em poucos elementos cranianos, ele representa um componente faunístico adicional na ZA de Riograndia do Triássico sul-brasileiro, na qual os cinodontes não-mamaliaformes de pequeno tamanho, intimamente relacionados à origem dos mamíferos, foram ecologicamente bem sucedidos e taxonomicamente diversos.

Palavras-chave: Cynodontia, Prozostrodontia, Supersequência Santa Maria, Triássico.

\section{REFERENCES}

ABDALA F. 2007. Redescription of Platycraniellus elegans (Therapsida, Cynodontia) from the Lower Triassic of South Africa, and the cladistic relationships of eutheriodonts. Palaeontology 50: 591-618.

AbDala F, BARBerena MC AND DoRnelles JE. 2002. A new species of traversodontid cynodont Exaeretodon from the Santa Maria Formation (Middle/Late Triassic) of Southern Brazil. Journal of Vertebrate Paleontology 22(2):313-325.

AbDala F AND Giannini NP. 2002. Chiniquodontid cynodonts: systematic and morphometric considerations. Palaeontology 45: 1151-1170.

ABDAla F AND RIBEIRO AM. 2000. A new therioherpetid cynodont from the Santa Maria Formation (middle Late Triassic), sourthern Brazil. Geodiversitas 22:589-596.

Abdala F, Ribeiro AM, Schultz CL, 2001. A rich cynodont fauna of Santa Cruz do Sul, Santa Maria Formation (Middle-Late Triassic), Southern Brazil. Neues Jahrb für Geol Paläontol Monatsh. 11, p. 669-687.

ABDALA F AND RiBEIRO AM. 2010. Distribution and diversity patterns of Triassic cynodonts (Therapsida, Cynodontia) in Gondwana. Palaeogeography, Palaeoclimatology, Palaeoecology 286: 202-217.

ARAúJo DC AND GonZAGA TD. 1980. Uma nova especie de Jachaleria (Therapsida, Dicynodontia) do Triassico do Brasil. In: Actas Del Ii Congreso Argentino De Paleontología Y Biostratigrafía. I Congresso Latinoamericano de Paleontología, Buenos Aires, p. 159-174.

BitTenCOURT J, DA Rosa AAS, SChULtz CL AND LANGER MC 2013. Dinosaur remains from the 'Botucaraí Hill'(Caturrita Formation), Late Triassic of south Brazil, and their stratigraphic context. Historical Biology: An International Journal of Paleobiology 2012: 1-13.

BITTENCOURT JS AND KELLNER AWA. 2009. The anatomy and phylogenetic position of the Triassic dinosaur Staurikosaurus pricei Colbert, 1970. Zootaxa 2079: 1-56.
BONAPARTE JF. 1971. Los tetrápodos del sector superior de la Formación Los Colorados, La Rioja, Argentina (Triásico Superior). I Parte. Opera Lilloana 22: 1-183

BONAPARTE JF. 2012. Evolution of the Brasilodontidae (Cynodontia-Eucynodontia). Historical Biology 25(5-6): 643-653.

BONAPARTE JF AND BARBERENA MC. 1975. A possible mammalian ancestor from the Middle Triassic of Brazil (Therapsida-Cynodontia). J Paleontol 49: 931-936.

BONAPARTE JF AND BARBERENA MC. 2001. On two advanced carnivorous cynodonts from the Late Triassic of Southern Brazil. Bull Mus of Comp Zool 156: 59-80.

BonAparte JF, FERIGOlO J AND Ribeiro AM. 1999. A new Early Late Triassic saurischian dinosaur from Rio Grande do Sul State, Brazil. National Sciences Museum Monographs 15: 89-109.

Bonaparte JF, Ferigolo J AND Ribeiro AM. 2001. A primitive Late Triassic "ictidosaur" from Rio Grande do Sul, Brazil. Palaeontology 44: 623-635.

BonAPARTE JF, MARTINELLI AG, SCHULTZ CL AND RUBERT R. 2003. The sister group of mammals: small cynodonts from the Late Triassic of southern Brazil. Rev Bras Paleontol 5: 5-27.

Bonaparte JF, Martinelli AG AND SChultz CL. 2005. New information on Brasilodon and Brasilitherium (Cynodontia, Probainognathia) from the Late Triassic of southern Brazil. Rev Bras Paleontol 8: 25-46.

BonApARTE JF, SCHULTZ CL, SOARES MB AND MARTINELli AG. 2010. La fauna local de Faxinal do Soturno, Triásico Tardío de Rio Grande do Sul, Brasil. Rev Bras Paleontol 13(3): 233-246.

Bonaparte JF, SoARes MB And Schultz CL. 2006. A new non-mammalian cynodont from the Middle Triassic of southern Brazil and its implications for the ancestry of mammals. Bulletin of the New Mexico Museum of Natural History \& Science 37: 599-607.

Bonaparte JF, SoARes MB AND MARTINElli AG. 2012. Discoveries in the Late Triassic of Brazil improve knowledge on the origin of mammals. Historia Natural, Fundación Felix de Azara, Tercera Serie 2012(2): 5-30.

BonAparte JF AND SUES HD. 2006. A new species of Clevosaurus (Lepidosauria: Rhynchocephalia) from the Upper Triassic of Rio Grande do Sul, Brazil. Palaeontology 49: 917-923.

Broom R. 1905. On the use of the term Anomodontia. Records of the Albany Museum 1: 266-269.

Cabreira SF, Schultz CL, Bittencourt J, SoAREs MB, ForTIER DC, Silva LM AND LANGER MC. 2011. New stem-sauropodomorph (Dinosauria, Saurischia) from the Triassic of Brazil Naturwissenschaften 98:1035-1040.

Cisneros JC AND Schultz CL. 2003. Soturnia caliodon n. g. n. sp., a procolophonid reptile from the Upper Triassic of Southern Brazil. Neues Jahrbuch für Geologie und Paläontologie, Abhandlungen 227: 365-380.

CROMPton AW AND JENKIns FA. 1968. Molar occlusion in Late Triassic mammals. Biol Rev 43: 427-458. 
CROMPtON AW AND LUO Z-X. 1993. Relationships of the Liassic mammals Sinoconodon, Morganucodon oehleri, and Dinnetherium. In: SZALAY FS, NOVACEK MJ AND MCKENNA MC (Eds), Mammal Phylogeny: Mesozoic Differentiation, Multituberculates, Monotremes, Early Therians and Marsupials. Springer-Verlag, New York. p. 30-44.

DiAs-DA-Silva S, DiAS EV AND Schultz CL. 2009. First record of stereospondyls (Tetrapoda, Temnospondyli) in the Upper Triassic of Southern Brazil. Gondwana Res 15(1): 131-136.

DORNELLES JEF. 1990. Registro sobre a ocorrência de dentes de um arcossáurio para a Formação Caturrita, Triássico Superior do Rio Grande do Sul. Ciência \& Natura 12: 99-101.

FERIGOLO J AND LANGER MC. 2007. A Late Triassic dinosauriform from south Brazil and the origin of the ornithischian predentary bone. Hist Biol 19(1): 23-33.

Furin S, Preto N, Rigo M, Roghi G, Gianolla P, Crowley J L AND BOWRING SA. 2006. High-precision U-Pb zircon age from the Triassic of Italy: Implications for the Triassic time scale and the Carnian origin of calcareous nannoplankton and dinosaurs. Geology 34(12): 1009-1012.

GolobofF PA, FARRIS JS AND NIXON KC. 2008. TNT, a free program for phylogenetic analysis. Cladistics 24: 1-13.

HAHN G, HAHN R AND GODEFroIT P. 1994. Zur stellung der Dromatheriidae (Ober-Trias) zwischen den Cynodontia und den Mammalia. Geol Palaeontol 28:141-159.

Holz M AND SCHERER CMS. 2000. Sedimentological and paleontological evidence of paleoclimatic change during the Southbrazilian Triassic: the register of a global trend towards a humid paleoclimate. Zentralblatt fur Geologie und Palaontologie (11-12): 1589-1609.

HoPSON JA. 1990. Cladistic analysis of therapsid relationships. J Vertebr Paleontol 10(3, Suppl.):28A.

Horn BLD, Melo TM, Schultz CL, Philipp RP, Kloss HP AND GOLDBERG K. 2014. A new third-order sequence stratigraphic framework applied to the Triassic of the Paraná Basin, Rio Grande do Sul, Brazil, based on structural, stratigraphic and paleontological data. J S Am Earth Sci 55: 123-132.

HOPSON JA AND BARGHUSEN H. 1986. An analysis of therapsid relationships. In: HOTTON N, MACLEAN PD, ROTH $\mathrm{JJ}$ and ROTH EC (Eds), The ecology and biology of mammal-like reptiles. Smithsonian Institution Press, Washington DC, p. 83-106.

HoPSON JA AND KITCHING JK. 2001. A probainognathian cynodont from South Africa and the phylogeny of nonmammalian cynodonts. Bull Mus Comp Zool 156: 5-35.

KEMP TS. 1982. Mammal-like Reptiles and the Origin of Mammals. Academic Press, London, 363 p.

Kischlat EE AND LuCAS SG. 2003. A phytosaur from the Upper Triassic of Brazil. J Ver Paleont 23: 464-467.

LANGER MC, ABDAla NF, Richter M AND BENTON MJ. 1999. A sauropodomorph dinosaur from the Upper Triassic, Carnian of southern Brazil. Comptes Rendus de 1'Academie des Sciences, serie II, fascicule A. Sciences de la Terre e des Planetes 329, 511-517.
LANGER MC, ESCURRA MD, BITTENCOUT JS AND Novas F. 2009. The origin and early evolution of dinosaurs. Biol Rev 85: 55-110.

LEAL LA, AZEVEDo SAK, KELlNER AWA AND DA RosA AAS. 2003. A new early dinosaur (Sauropodomorpha) from the Caturrita Formation (Late Triassic), Paraná Basin, Brazil. Zootaxa 690:1-24.

LIU J AND OLSEN PE. 2010. The phylogenetic relationships of Eucynodontia (Amniota, Synapsida). J Mamm Evol 17: 151-176.

LUCAS SG AND LUO Z-X. 1993. Adelobasileus from the Upper Triassic of west Texas: the oldest mammal. J Vertebr Paleontol 13: 309-334.

LuO Z-X. 1994. Sister-group relationships of mammals and transformations of diagnostic mammalian characters. In: FRASER NC AND SUES HD (Eds), In the Shadow of the Dinosaurs. Cambridge University Press, Cambridge, p. $98-128$.

LUO Z-X. 2007. Transformation and diversification in the early mammalian evolution. Nature 450: 1011-1019.

LuO Z-X AND CROMPTON AW. 1994. Transformation of the quadrate (incus) through the transition from nonmammalian cynodonts to mammals. J Vertebr Paleontol 14: 341-374.

Luo Z-X, Kielan-Jaworowska Z AND CIFELLI RL. 2002. In quest for a phylogeny of Mesozoic mammals. Acta Paleontol Pol 47: 1-78.

LuO Z-X, Kielan-Jaworowska Z AND CIFELli RL. 2004. Evolution of dental replacement in mammals. Bull Carnegie Mus Nat Hist 36: 159-175.

MARTinelli AG AND BonAPARTE JF. 2011. Postcanine replacement in Brasilodon and Brasilitherium (Cynodontia, Probainognathia) and its bearing in cynodont evolution. In: CALVO J, PORFIRI J, RIGA BG AND DOS SANTOS D (Eds), Dinosaurios y Paleontología desde América Latina, Anales del III Congreso Latinoamericano de Paleontología (Neuquén, 2008), Editorial de la Universidad Nacional de Cuyo, Mendoza, p. 179-186.

Martinelli AG, Bonaparte JF, SCHULtz CL AND RUBERT R. 2005. A new tritheledontid (Therapsida, Eucynodontia) from the Late Triassic of Rio Grande do Sul (Brazil) and its phylogenetic relationships among carnivorous nonmammalian eucynodonts. Ameghiniana 42:191-208.

Martinelli AG AND Rougier GW. 2007. On Chaliminia musteloides Bonaparte (Cynodontia, Tritheledontidae) and the phylogeny of the Ictidosauria. J Vertebr Paleontol 27: 442-460.

Martinez RN, Fernandez E AND Alcober OA. 2013. A new non mammaliaform eucynodont from the Carnian-Norian Ischigualasto Formation, northwestern Argentina. Rev Bras Paleontol 16: 61-76.

Martinez RN, MAY CL AND Forster CA. 1996. A new carnivorous cynodont from the Ischigualasto Formation (Late Triassic, Argentina), with comments on eucynodont phylogeny. J Vertebr Paleontol 16: 271-284. 
Martinez RN, Sereno PC, Alcober OA, Colombia CE, RENNE PP, MONTAÑEz IP AND CURRIE BS. 2011. A basal dinosaur from the Dawn of the Dinosaur era in Southwestern Pangaea. Science 331: 206-210.

OLIVEIRA EV. 2006. Reevaluation of Therioherpeton cargnini Bonaparte and Barberena, 1975 (Probainognathia, Therioherpentidae) from the Upper Triassicof Brazil. Geodiversitas 28: 447-465.

Oliveira TV, Martinelli AG And SoAres MB. 2011. New material of Irajatherium hernandezi Martinelli, Bonaparte, Schultz \& Rubert 2005 (Eucynodontia, Tritheledontidae) from the Upper Triassic (Caturrita Formation, Paraná Basin) of Brazil. Paläontologische Zeitschrift 85: 67-82.

Oliveira TV, SoARes MB AND Schultz CL. 2010. Trycidocynodon riograndensis gen. nov. et sp. nov. (Eucynodontia), a new cynodont from the Brazilian Upper Triassic (Santa Maria Formation). Zootaxa 2382: 1-71.

OWEN R. 1861. Palaeontology, or a Systematic Summary of Extinct Animals and Their Geological Relationships. Adam and Black, Edinburgh, 463 p.

Rodrigues PG, RUF I AND SCHUltz CL. 2012. Digital Reconstruction of the Otic Region and Inner Ear of the non-mammalian cynodont Brasilitherium riograndensis (Late Triassic, Brazil) and its relevance to the evolution of the mammalian ear. J Mamm Evol 20(4): 291-307.

RODRIGUES PG, RUF IAND SCHULTZ CL. 2013. Study of a digital cranial endocast of the non-mammaliaform cynodont Brasilitherium riograndensis (Later Triassic, Brazil) and its relevance to the evolution of the mammalian brain. Palaontologische Zeitschrift 88: 329-352.

Rogers RR, Swisher III CC, SERENo PC, Monetta AM, FORSTER CA AND MARTíNEZ RN. 1993. The Ischigualasto tetrapod assemblage (Late Triassic, Argentina) and 40Ar/39Ar dating of dinosaur origin. Science 260: 794-797.
Rowe T. 1988. Definition, diagnosis, and origin of Mammalia. J Vertebr Paleontol 8: 241-264.

RUBERT R AND SCHULTZ CL. 2004. Um novo horizonte de correlação para o Triássico Superior do Rio Grande do Sul. Pesq Geociênc 31: 71-88.

Ruff I, MAier W, Rodrigues PG AND Schultz CL. 2014. Nasal anatomy of the non-mammaliaform cynodont Brasilitherium riograndensis (Eucynodontia, Therapsida) reveals newi into mammalian evolution. The Anatomical Record 297(11): 2018-2030.

Sidor CA AND Smith RMH. 2004. A new galesaurid (Therapsida: Cynodontia) from the Lower Triassic of South Africa. Palaeontology 47: 535-556.

SoARES MB, SchUltz CL AND Horn BLD. 2011. New information on Riograndia guaibensis Bonaparte, Ferigolo \& Ribeiro, 2001 (Eucynodontia, Tritheledontidae) from the Late Triassic of southern Brazil: anatomical and biostratigraphic implications. An Acad Bras Cienc 83: 329-354.

SuEs H-D. 2001. On Microconodon, a Late Triassic cynodont from the Newark Supergroup of Eastern North America. Bull Mus Comp Zool 156(1): 37-48.

WIBLE JR AND HopSON JA. 1993. Basicranial evidence for early mammal phylogeny. In: SZALAY FS, NOVACEK MJ AND MCKENNA MC (Eds), Mammal Phylogeny: Mesozoic Differentiation, Multituberculates, Monotremes, Early Therians and Marsupials. Springer Verlag, New York, p. 45-62.

Zerfass H, LaVINA EL, SCHULTZ CL, GarCIA AJV, FACCINI UF AND Chemale JR F. 2003. Sequence stratigraphy of continental Triassic strata of Southernmost Brazil: a contribution to Southwestern Gondwana palaeogeography and palaeoclimate. Sediment Geol 161: 85-105. 


\section{Appendix 1. Phylogenetic Analysis}

Botucaraitherium was included into the phylogenetic framework of Liu and Olsen (2010), which constitutes the largest matrix of non-mammaliaform cynodonts to date. This matrix is based upon several previous contributions, including that of Hopson and Barghusen (1986), Rowe (1988), Wible and Hopson (1993), Lucas and Luo (1993), Luo (1994), Luo and Crompton (1994), Martínez et al. (1996), Hopson and Kitching (2001), Luo et al. (2002), Bonaparte et al. (2003, 2005), Sidor and Smith (2004), Martinelli et al. (2005), Abdala (2007), Martinelli and Rougier (2007), and Oliveira et al. (2010).

The data matrix of Liu and Olsen (2010) was modified for the current analysis:

\section{1) CHANGES IN SCORINGS OF TAXA:}

Character 01: Prozostrodon changes from 1 to 2 (based on Bonaparte and Barberena 2001). Riograndia changes from 0 to 1 (based on Bonaparte et al. 2001, Soares et al. 2011)

Character 07: Therioherpeton changes from ? to 1 (based on Bonaparte and Barberana 2001, Oliveira 2006).

Character 11: Brasilodon changes from 1 to 2.

Character 13: Prozostrodon changes from 0 to 1 (based on UFRGS-PV-0248-T; Martinelli et al. 2005, Martinelli and Rougier 2007).

Character 14: Prozostrodon changes from 1 to 2 (based on UFRGS-PV-0248-T; Martinelli et al. 2005, Martinelli and Rougier 2007).

Character 19: Riograndia changes from ? to 0 (based on Bonaparte et al. 2001, Soares et al. 2011).

Character 26: Riograndia changes from ? to 0 (based on Soares et al. 2011).

Character 27: Riograndia changes from ? to 1 (based on Bonaparte et al. 2001).

Character 30: Prozostrodon changes from ? to 2.

Character 35: Riograndia changes from 2 to 1. Brasilodon changes from 2 to 1 (based on Bonaparte et al. 2005).

Character 37: Brasilodon changes from ? to 1 (based on Bonaparte et al. 2005).

Character 93: Prozostrodon changes from 0 to 1 (based on UFRGS-PV-0248-T).

Character 96: Exaeretodon and Scalenodon angustifrons change from 1 to 0 (due to change in character definition).

Character 98: Brasilodon changes from ? to 0.

Character 103: Prozostrodon changes from 0 to 1.

Character 119: Brasilodon changes from 0 to $0+1$.

\section{2) CHANGES IN CHARACTER DEFINITION:}

Character 37 (modified according to Hopson and Kitching 2001, Martinelli and Rougier 2007: ch. 47): Length of palatine relative to maxilla in secondary palate: shorter (0); about equal (1); longer (2).

Character 96 (redefined): Incisors: all of similar size (0); some incisor large (1).

Character 106 (new state and re-ordered): Upper postcanine roots: single (0); constricted root, with incipient longitudinal groove (1); divided into two longitudinal aligned roots (2); multiple roots (more than two) (3).

Character 107 (new state and re-ordered): Lower postcanine roots: single (0); constricted root, with incipient longitudinal groove (1); divided (2).

\section{3) ADDITION OF NEW TAXA:}

Brasilitherium riograndensis (Bonaparte et al. 2003, 2005, 2012).

Botucaraitherium belarminoi (this paper). 


\section{Appendix 2. Data matrix}

Distribution of character-states for the 145 characters based on Liu and Olsen (2010) plus the modification in Appendix 1, among Procynosuchus delaharpeae as outgroup and 32 ingroup terminal taxa considered in the analysis.

\section{Procynosuchus delaharpeae}

$0000000100000000000000000000000000000000000000000000000000000001[01] 00000000000000000$ 000001000000000100010000000--00-0000000000000-00000000000000002

\section{Galesaurus planiceps}

010000000000000000100000100001100000000000000000000000000000000000000000000001000010 0000000001100100000010000--00-1000000001100????00??0??0000000

\section{Thrinaxodon liorhinus}

01[01]0000000000000000000000000001110000000000000000000000000000000000000001001010000 100000110001100000010000000--00-1000000001100-00000000000?0000?

\section{Platycraniellus elegans}

$0110000000000000001100000000010110000000 ? ? 00000000 ? 0000000000000000000101 ? ? 101000 ? 101$ 0?0??0001?0?100000000000--0?-0?000?????????????????????????

\section{Cynognathus crateronotus}

$00000000000000001021002110000011100001011100010100 ? 0000000000000100000111001011011201$ 011120001101000100010000--00-1001000000111000000110000000000

\section{Diademodon tetragonus}

[01]0000000000000001022012111000111100000011100010100000000[01]000000000000000100101111 $120101112113110100012001000100100 ? 000100001111000000110000000000$

\section{Trirachodon berryi}

$11100100[01] 00000001121011111010011101002011100010100000002100000000000110111020110111$ $010111211311010001211100020110100101 ? ? ? 01111000000 ? ? ? ? 00000000$

\section{Sinognathus gracilis}

1020?100100000??11010011110?1?1?1010?0011000010100???????00000?000?01101110201101110101 $1 ? ? 113120000002 ? 0 ? 00 ? 201100 ? 0201$ ?????????????????????????

\section{Langbergia modisei}

$001000000000000001210111110100111010000110000101 ? 0 ? 000 ? 21 ? ? 0000000001 ? 0 ? 11 ? ? ? ? 101110101$ $11211311010001200100020110100101 ? ? ? ? ? 1 ? ? ? ? ? ? ? ? ? ? ? ? ? ? ? ? ? ?$

\section{Pascualgnathus polanskii}

1020?100100000001122012111011?1110100001??000101?0???0?2?00000???0?0??????????[01]0?12010 $11 ? ? 113210000002[12][12] 000-110100-12010 ? ? ? 1101 ? ? 0000 ? ? 1000000000$ 


\section{Luangwa drysdalli}

??00?1000?0000010121001111????1110?00001???00101000000?2??00000???0???????????1011201011 ??113110100012[12][12]000-202100-12010???110110000???1100000000

\section{Massetognathus pascuali}

0111110010000000110101111101121110200001000001010000001211000000000011011102011011 [12] 01011??11311021110211000-222100-120100000101101000??1100000000

\section{Exaeretodon argentinus}

$00111110100000111121012111011211101[01] 00010 ? 00010100010002110000000000 ? 101 ? ? ? ? 01101121$ $1011 ? ? 113210010102[12][12] 000-120100-122100000001101001111100000000$

\section{Scalenodon angustifrons}

??10?1?0000000??1101012111?????1101?0??1??00010100?0000211000000?000??0?????0?[01]0?12??0 $11 ? ? 113110100012[12][12] 000-202100-1201 ? ? ? ? ? ? ? ? ? ? ? ? ? ? ? ? ? ? ? ? ? ? ? ?$

\section{Scalenodon hirschoni}

???0010?????001?11?????111011211101?0?0?0??00????????????1?000?0?????1??1?0?0?[01]??1???011 ??113220001002[12][12]000-222100-1201??????????????????????????

\section{Chiniquodon theotonicus}

11101010100000101011000001011 [12]11112100011000010100000001000000000000?1?01???11101120 1011120001100000000010000--00-100000??000011010001110000?0000

\section{Lumkuia fuzzi}

??1000101000000?00000000010?1201101001010100010010?0000001000000000000001000011011201 000120001100000000010000--00-10000?????001???????????0?????

\section{Ecteninion lunensis}

$001 ? ? 0021000002000000000000 ? 1[01] 11100002011100010100 ? 10001010000000000110011021110110$ 01011??00011000001[01]0010000--00-?00000???1??110??0????0???????

\section{Probainognathus jenseni}

0110100210000010010110000101121111100001110001000000001100000000000011001102111021001 011120001100000010000000--00-00110000?000110???0??11000?0000

\section{Therioherpeton cargnini}

?????0121211122?2100??0????????1111???????????????????????????????????????????????????????00 0????????0?0?1100--00-?00000??1?00?????????1111110011

\section{Riograndia guaibensis}

0113101211111221?10???0000111201111120110001020000?0000102000010001121102?13????0030111 1??001211001100[12]001100--00-10100?????????????????????????

\section{Pachygenelus monus}

$20131012111112212100100000011201112120110001020000100001020000101 ? ? 121102213132020301$ 111120012210010001000010--00-002001???0001111101??1111111111 


\section{Prozostrodon brasiliensis}

21?010?2????1221?1?????????112?1111?1????????????????????????????????????????????0301111??00 10000000111001100--00-001000???000?????0???1111110000

\section{Botucaraitherium belarminoi}

?????0??????????????????????????????????????????????????????????????????????????0???11????01 ??????001?001110--01-00????????????????????????????

\section{Brasilodon quardangularis}

[01]000?0121121122120001000?00?1201111102110001021001?0?112220?00111011211022131320?03 01111??0011100001011001110--01-001[01]1??????0111??11????????????

\section{Brasilitherium riograndensis}

0000?0121121122120001000000?1201111102110001021011?01112220???11?011211022131320103011 11??0010100001011001110--01-001[01]1???????????11???????1111

\section{Tritylodon longaevus}

102-1111110112211102001111011211102122110000110110110102121111011010311022031202003 11111??1132210-22-222-32-2-1100-03221??????210??????1?????1111

\section{Oligokyphus major}

[12]??-1111?10112???102010110?1?2?1??21????????110?10110102?211110110003100220312020 0311111??1132110-22-222-32-2-1100-0322111100?2101111??1121111111

\section{Bienotherium yunnanense}

102-11111101122111?201?111011211102122110000110110110?02?01111?110?031??22131?02003 11111??1132110-22-222-32-2-1100-03221??????210??11??????111111

\section{Kayentatherium wellesi}

102-11111?0112211102011111111201102122110000110110110102121111?110?0311022131202003111 11121132110-22-222-32-2-1100-0322?11100021011?1111121??1111

\section{Adelobasileus cromptoni}

???????01121?2????????????????0??????2110001021011?21112210000101110?????????????????????? ???????????????0?????0??1?????????????????????????????

\section{Sinoconodon rigneyi}

0002?0101121122120001000?01?1211112102110011031011?21112221011101010????????0?302030111 2??2001000001001002210--00-10101?????????????????????????

\section{Morganucodon oehleri}

0?02?0101121122120002?0000111111112102110011032011121112220112111111211022132430203011 12122221000001011002210--01-0010111111001111111??1121111111 


\title{
A new prozostrodontian cynodont (Therapsida) from the Late Triassic Riograndia Assemblage Zone (Santa Maria Supersequence) of Southern Brazil
}

\author{
MARINA B. SOARES, AGUSTÍN G. MARTINELLI and TÉO V. DE OLIVEIRA
}

\author{
ABSTRACT \\ Linha 1 - leia-se 'We report here on...' \\ Linha 2 - leia-se 'from the Late Triassic Riograndia...' \\ Linha 4 - leia-se 'includes the left...' \\ Linha 10 - leia-se 'positioned it as a more derived taxon...' \\ Linha 11 - leia-se 'tritylodontids, being the sister-taxon...' \\ Linha 11 - leia-se 'Brasilitherium plus Mammaliaformes' \\ Linha 13 - leia-se '...cynodonts, closely related...'
}

\section{INTRODUCTION}

Coluna 2, linha 2 - adicionar '(Abdala and Ribeiro 2010)' após 'Malagasy faunas

Coluna 2, última linha - leia-se 'based upon poorly preserved'

\section{PÁGINA 2}

Coluna 1, parágrafo 2, linha 7 - leia-se '...and postorbital, constricted root...'

Coluna 1, parágrafo 2, linha 15 - leia-se '...lower jaw (unexpected for Therioherpeton based on its skull), we consider...' [ [ adicionar o trecho entre parênteses e remover o trecho que começa com 'that differs' até 'Terioherpeton's one'

Coluna 2, linha 7 - leia-se '(sensu Martinelli et al...'

Coluna 2, linha 10 - leiase 'cynodonts from this...'

Coluna 2, linha 22 - colocar uma vírgula após 'e.g.'

Coluna 2, linha 25 - leia-se 'et al. 2012, 2013, Ruff et al. 2014)'

Coluna 2, linha 30 - colocar uma vírgula após 'e.g.'

Coluna 2, linha 33 - colocar uma vírgula após 'e.g.'

\section{PÁGINA 3}

Coluna 1 , linha 1 - leia-se '...do Sul, Brazil. The new...'

Coluna 2, linha 2 - leia-se '...Riograndia AZ. The new specimen contributes to the understanding of the non-mammaliaform prozostrodontian diversity.' (termina aqui o parágrafo)

Coluna 2, parágrafo 2 , linha 8 - colocar vírgula após 'e.g.' 


\section{PÁGINA 4}

Coluna 1, linha 21 - substituir 'prosauropod' por plateosaurid

Coluna 1, linha 24 - leia-se ‘...(1999), and new specimens with sauropodomorph affinities (Bittencourt et al. 2013), plus the dinosauriform...'

Coluna 1, linha 30 - leia-se '1990), and a stereospondyl...'

Coluna 1, linha 32 - remover 'and new materials...' até ‘...(Bittencourt et al. 2013).'

Coluna 1, última linha - leia-se 'Bonaparte 1971, see also comments in Martinelli and Rougier 2007)'

Coluna 2, linha 2 - leia-se 'crops out along the...'

Coluna 2, linha 4 - leia-se ' $\left(29^{\circ} 40^{\prime} 53^{\prime}\right.$ ' $\mathrm{S}$; $52^{\circ} 50^{\prime} 28^{\prime}$ ' W). This site is characterized...'

Coluna 2, linha 10 - leia-se 'The holotype of the new cynodont...'

Coluna 2, parágrafo 2, linha 11 - leia-se 'of the crown of upper postcanines slightly...'

Coluna 2, parágrafo 2, linha 13 - remover os parênteses em (a)

\section{PÁGINA 6}

Coluna 1, parágrafo 3, linha 4 - leia-se '(Fig. 3). Only the lower canine, one upper and...'

Coluna 1, parágrafo 4 , linha 4 - substituir size por side

Coluna 1, parágrafo 4, linha 4 - leia-se '...skull. One of the fragments, which preserves the left canine, has the external surface anteroposteriorly concave,...'

Coluna 1, parágrafo 4, linha 6 - após root adicionar '(Fig. 3A)'

Coluna 1, parágrafo 4, linha 10 - leia-se 'the two following ones (described later) (Fig. 3B)'

Coluna 1, última linha - leia-se '...large exit of the infraorbital branch of the trigeminal...'

Coluna 2, linha 1 - leia-se 'The dentary...'

Coluna 2 , linha 2 - leia-se 'The jaw is anteroposteriorly larger than...'

Coluna 2, linha 11 - colocar vírgula após 'e.g.'

Coluna 2, linha 18 - leia-se 'be transversely wide at the...'

Coluna 2, linha 19 - leia-se 'although its shape seems to be...'

Coluna 2, linha 26 - colocar '(Fig. 4A)' após postcanine series

Coluna 2, parágrafo 2, linha 2 - adicionar '(Fig. 4A)' após dorsoventrally

Coluna 2, última linha - colocar vírgula após e.g.

\section{PÁGINA 8}

Coluna 1, linha 2 - adicionar (Fig. 3A) após crenulations

Coluna 1, parágrafo 2, linha 2 - substituir Fig. 4 por Fig. 3A

Coluna 1, parágrafo 3, linha 22 - colocar '(Fig. 3C)' após dorsal base

Coluna 1 , última linha - colocar vírgula após e.g.

Coluna 2, parágrafo 2 - este parágrafo deve ficar como abaixo:

The upper postcanine pattern of the Botucaraitherium is quite different from those of the tritheledontids (Irajatherium, Chaliminia), in which there are a mesiodistally compressed and transversely broad main cusp, with small mesial and distal cusps (with a labial cingulum in the postcanines of Pachygenelus; Gow 1980, Martinelli et al. 2005, Martinelli and Rougier 2007). Botucaraitherium also differs from Riograndia because the latter taxon has up to nine cusps mesiodistally aligned without any cingulum 
(Bonaparte et al. 2001, Soares et al. 2011). The upper postcanines of Prozostrodon display four aligned cusps (A, B, C, D) (Bonaparte and Barberena 2001) without lingual cusps or any cingular cuspules. Thus, the upper postcanines of Botucaraitherium differ significantly from those of Prozostrodon in having three main cusps (instead of four) plus accessory labial cingular cuspules (Fig. 5A, B).

Coluna 2, parágrafo 3, linha 3 - leia-se '(Fig. 5A, C)'

Coluna 2, parágrafo 3, linha 5 -adicionar 'non-mammaliaform' antes de 'prozostrodontian.'

Coluna 2, parágrafo 3, penúltima linha - substituir 'cuspule' por 'cusp'

Coluna 2, parágrafo 4 - este parágrafo deve ficar como abaixo:

'Botucaraitherium is differentiated from brasilodontids by a notoriously more bulbous crown and two (not one) mesio-labial accessory cusps. These features have never been observed even in the largest specimens of the aforementioned brasilodontids. Therefore, we considered this feature as unique of Botucaraitherium, since in the large sample of brasilodontids from the Riograndia AZ, this condition was never observed.'

Coluna 2, parágrafo 5 - leia-se 'In addition to the only preserved upper postcanine, the maxillary fragment preserves the root of the two following teeth. The roots increase in size posteriorly and are 8-shaped in cross-section...

\section{PÁGINA 9}

Coluna 1, linha 2 - leia-se '...lingual sides, with each lobe having its own root canal.'

Coluna 1 , parágrafo 2 , linha 5 - leia-se '...it is impossible to deduce the number and size of the other incisors (Fig. 4A). In Brasilodon ...’

Coluna 1 , parágrafo 2 , última linha - '...Botucaraitherium is likely to be the same.'

Coluna 1, parágrafo 3, linha 1 - substituir (Fig. 3) por (Fig. 4A)

Coluna2, linha 9 - colocar vírgula após e.g.

Coluna 2, linha 12 - colocar vírgula após e.g.

Coluna 2, parágrafo 2, linha 2 - substituir (Fig. 3) por (Fig. 4A)

Coluna 2, parágrafo 2, linha 4 - leia-se '...obscures the anatomy of the tooth.'

Coluna 2, parágrafo 2, linha 6 - substituir 'possess' por 'show'

\section{PÁGINA 10}

Coluna 1, penúltima linha - substituir 'which better preserved' por 'that better preserve'

Coluna 2, linha 5 - após 'shelf' adicionar '(Fig. 4B, C)'

Coluna 2, parágrafo 3, linha 1 - substituir 'pattern' por 'morphology'

Coluna 2, parágrafo 3, linha 7 - colocar vírgula após e.g.

Coluna 2, parágrafo 3, linha 9 - substituir 'cups' por 'cusps'

Coluna 2, parágrafo 4, linha 2- substituir noteworthy por 'possible'

Coluna 2, parágrafo 4, linha 5 - leia-se 'The anterior most postcanine (i.e., labeled along the text as pc1) partially inserted...

Coluna 2, parágrafo 4, linha 11 - após ‘Brasilitherium' até o fim do parágrafo, deve ser lido da seguinte maneira 
'being apparently polyphyodonty taxa (Bonaparte et al. 2003, 2005, Martinelli and Bonaparte 2011). It should be emphasized that the sequence of postcanine eruption and the number of replacement per locus at the non-mammaliaform prozostrodontians-mammaliaforms boundary is a matter still poorly understood. (remover Deep analyses... até o final)

\section{PÁGINA 11}

Coluna 1, parágrafo 1 - após 'the same AZ.' Até o fim do parágrafo, deve ser lido da seguinte maneira

There are no recorded specimens of Brasilodon and Brasilitherium in the Botucaraí Hill Site. In turn, these taxa are relatively abundant in the Sesmaria do Pinhal 1 Site, located about 600 meters away (Bonaparte et al. 2003, 2005). In addition, within the Botucaraí region there is a record a Brasilitheriumlike teeth in Sesmaria do Pinhal 3 Site, located about 1000 meters away from the Botucaraí Hill Site (Soares et al. 2011, Bittencourt et al. 2013).

Coluna 1, parágrafo 2, linha 3 - leia-se ‘...2003, 2005), due to the morphology of the upper and lower postcanines (see Fig. 5, 6). They can be...

Coluna 2, linha 1 - leia-se ...to Prozostrodon, from the older Hyperodapedon AZ, is also noteworthy.' (finalizar a frase aqui, removendo 'since this taxon...' até 'Hyperodapedon AZ')

Coluna 2, linha 9 - substituir more notorious por 'stronger'

Coluna 2, linha 9 - leia-se 'due to the fact that the teeth'

Coluna 2, linha 10 - substituir being por 'are'

\section{PÁGINA 12}

Coluna 1, linha 6 - substituir taxa por 'taxon'

Coluna 1, parágrafo 1, última linha - substituir 'units' por 'taxa'

Coluna 2, parágrafo 2, linha 4 - substituir 'a less inclusive' por 'more derived'

Coluna 2, parágrafo 2, linha 4 - substituir 'but outside' por 'as the sister group to'

Coluna 2, parágrafo 3, linha 2 - após 'AZ' adicionar '(Fig. 8)

Coluna 2, parágrafo 3, linha 3 - substituir 'Prozostrodontia' por 'non-mammaliaform prozostrodontians'

Coluna 2, parágrafo 3, linha 4 - substituir its por 'their'

Coluna 2, parágrafo 3, linha 7 - leia-se '...steps related to the origin of mammaliaforms have taken place.

PÁGINA 13

Acknowledgments, linha 3 - após 'Rodrigues' colocar (Candelária, RS)

Acknwoledgments, linha 7 - Antes de 'Funds were...' adicionar a seguinte frase: 'We also thank to Jorge Blanco for the skillful drawing of Botucaraitherium (Fig. 8).'

Acknowledgments, última linha - adicionar a frase seguinte no final do parágrafo: 'We are grateful for the comments of Dr. Guillermo Rougier, Dr. Ricardo Martinez, the anonymous reviewer and the Editor of AABC, Dr. Alexander Kellner, which greatly improved the Ms.'

\section{RESUMO}

Coluna 1, Linha 1 - substituir 'Aqui é reportado' por 'Nós reportamos aqui'

Coluna 1, Linha 2 - adicionar 'do Triássico Tardio' antes de 'da Zona de Assembleia'

Coluna 1 , Linha 6 - substituir 'uma' por 'a' 
Coluna 1, penúltima linha - substituri 'menos inclusivo' por 'mais derivado'

Coluna 1, última linha - substituir 'e como táxon-irmão' por 'sendo o táxon-irmão'

Coluna 2, linha 1 - leia-se '...mais Mammaliaformes.'

\section{REFERÊNCIAS}

Adicionar a referência abaixo antres de Araújo and Gonzaga 1980:

ABDAla F AND RiBeIRo AM. 2010. Distribution and diversity patterns of Triassic cynodonts (Therapsida, Cynodontia) in Gondwana. Palaeogeography, Palaeoclimatology, Palaeoecology 286: 202-217.

Adicionar a referência abaixo antes de Sidor and Smith 2004:

RUfF I, MAIER W, RODRIGUES PG AND SCHUltZ CL. 2014. Nasal anatomy of the non-mammaliaform cynodont Brasilitherium riograndensis (Eucynodontia, Therapsida) reveals newi into mammalian evolution. The Anatomical Record 297(11): 2018-2030.

FIGURA 3 - substituir pela figura 3 enviada pela autora

FIGURA 4 - é a figura 3 anterior

FIGURA 8 - adicionar a nova figura

PÁGINA 132 - Coluna 1, parágrafo 2, linha 16 - adicionar espaço entre consider e that

PÁGINA 133 - Coluna 2, linha 2 - substituir

'In our view, the new specimen contributes to the clarification of the characters transformation within nonmammaliaform prozostrodontians and on the understanding of its diversity.'

Por

'The new specimen contributes to the understanding of the non-mammaliaform prozostrodontian diversity.'

PÁGINA 134 - Coluna 2, linha 4 - adicionar um ponto antes de 'This'

PÁGINA 136 - Coluna 1, penúltima linha - colocar um 'the' após 'exit of'

PÁGINA 138 - Coluna 2, parágrafo 3 - o parágrafo 3 deve ser exatamente como abaixo:

Botucaraitherium is differentiated from brasilodontids by a notoriously more bulbous crown and two (not one) mesio-labial accessory cusps. These features have never been observed even in the largest specimens of the aforementioned brasilodontids. Therefore, we considered this feature as unique of Botucaraitherium, since in the large sample of brasilodontids from the Riograndia AZ, this condition was never observed.

Coluna 2, parágrafo 4 - o parágrafo 4 deve ser exatamente como abaixo:

In addition to the only preserved upper postcanine, the maxillary fragment preserves the root of the two following teeth. The roots increase in size posteriorly and are 8-shaped in cross-section, in which the longitudinal groove is present in both labial and lingual sides, with each lobe having its own root canal.

PÁGINA 140 - Coluna 1, linha 5 - colcoar vírgula após e.g. / Coluna 2, linha 13 - leia-se ‘preserve' (remover o d)

PÁGINA 141 - Coluna 1, linha 1 - leia-se 'most postcanines were lost and not replaced. The anterior most postcanine (i.e., labeled along the text as pc1) partially inserted in the alveolus...'

PÁGINA 142 - Coluna 1, linha 2 - remover a parte que era observação desta assessoria: 'finalizar a frase aqui, removendo 'since this taxon was found in the older Hyperodapedon AZ.' 
TÍTULO DO TRABALHO - Colocar itálico em Riograndia

PÁGINA 2 - Coluna 1, parágrafo 3, linhaq 3 - remover 'Ferigolo and Ribeiro, 2001'

PÁGINA 134 - Coluna 1, linha 21 - remover 'and' antes do 'the'

PÁGINA 138 - Coluna 2, linha 5 - colocar itálico em 'Prozostrodon'

PÁGINA 141

Coluna 2, linha 7 - leia-se 'is a record of Brasilitherium-like...'

Coluna 2, parágrafo 2, linha 3 - remover espaço entre '...2003, 2005)’ e a vírgula

PÁGINA 143

Coluna 1, parágrafo 2, linha 2 - colocar itálico em Botucaraitherium

Coluna 1, parágrafo 2, linha 3 - colocar itálico em Botucaraitherium

Coluna 1, parágrafo 2, linha 5 - colocar itálico em Brasilodon

Coluna 1, parágrafo 2, linha 6 - colocar itálico em Botucaraitherium

Acknowledgments, linha 9 - colocar itálico em Botucaraitherium

PÁGINA 1674 - segunda coluna: excluir maieri

PÁGINA 1675 - A legenda da Fig. 1 está incompleta: Substituir por:

Fig. 1 - A: Geographical location of the Santa Maria Supersequence (Paraná Basin) in the state of Rio Grande do Sul, Brazil. B: Chronostratigraphy of the southern Brazilian Triassic, showing the four Assemblage Zones (AZ) based on tetrapods context. From Horn et al. 2004. Biostratigraphy after Soares et al. 2011. Abbreviations: Any, Anisian; Car, Carnian; Ind, Induan; Lad, Ladinian; Nor, Norian; Ole, Olenekian; Rha, Rhaetian.

PÁGINA 1674 - primeira coluna: ,amongothers, - SEPARAR!

PÁGINA 1677 - Legenda da Fig. 2 errada. Substituir por:

Fig. 2 - A: Road map with City of Candelária indicated. B: View of the Botucaraí Hill site, southern margin of BR 287 road, with the indication of the fossiliferous level. C: Log of the Botucaraí Hill Site.

PÁGINA 1678 - Segunda coluna: O correto é Fig. 4 e não Fig. 3

PÁGINA 1679 - Legenda da Fig. 3: excluir Gray areas (está repetido)

PÁGINA 1680 - segunda coluna: colocar Riograndia em itálico

PÁGINA 1683 - primeira coluna: juntar anterior most = anteriormost

PÁGINA 1684 - primeira coluna: retirar ‘

PÁGINA 1685 - primeira coluna: Acrescentar: dentition na frase

... dentary and dentition give support ...

PÁGINA 1685 - segunda coluna: substituir Vertebrate collection por Paleovertebrates

PÁGINA 1688 - as referências não estão em duas colunas ...

PÁGINA 1689 - Riograndia em itálico

PÁGINA 1691 - escrever guaibensis ao invés de guaibaensis 